\title{
SAVANNAH RIVER PLANT CRITICALITY DOSIMETRY SYSTEM
}

C. N. WRIGHT

J. E. HOY

W. F. SPLICHAL, JR.
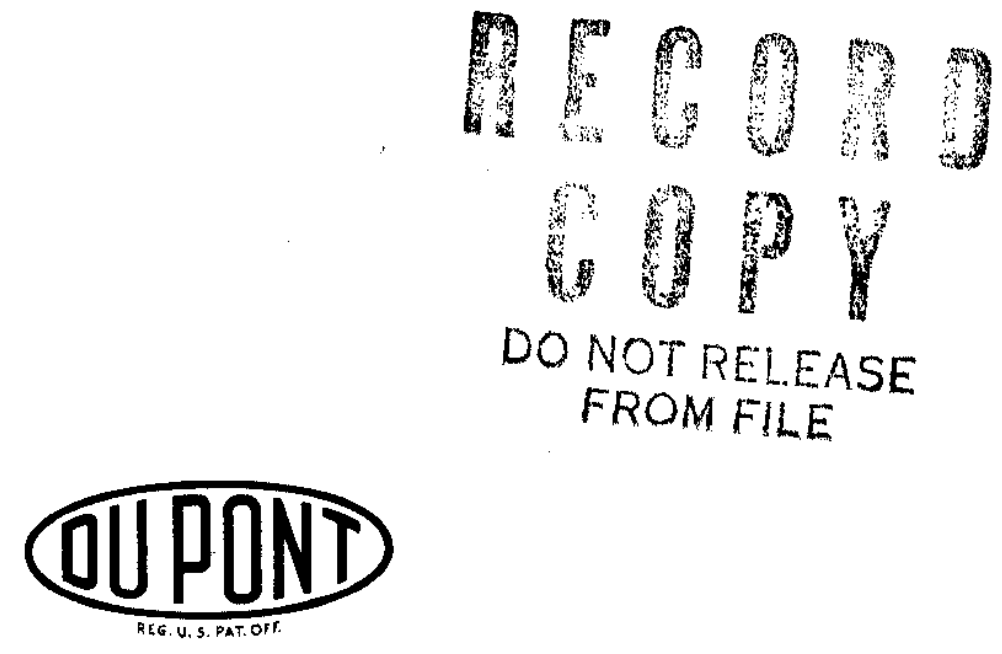

Savannah River Laboratory

Aiken, South Carolina 


\section{LEG A L NOTICE}

This report was prepared as an account of Government sponsored work. Neither the United States, nor the Commission, nor any person acting on behalf of the Commission:

A. Makes any warranty or representation, expressed or implied, with respect to the accuracy, completeness, or usefulness of the information contained in this report, or that the use of any information, apparatus, method, or process disclosed in this report may not infringe privately owned rights; or

B. Assumes any liabilities with respect to the use of, or for damages resulting from the use of any information, apparatus, method, or process disclosed in this report.

As used in the above, "person acting on behalf of the Commission" includes any employee or contractor of the Commission, or employee of such contractor, to the extent that such employee or contractor of the Commission, or employee of such contractor prepares, disseminates, or provides access to, any information pursuant to his employment or contract with the Commission, or his employment with such contractor.

Printed in USA. Price $\$ 2.00$

Avallable from the Clearinghouse for Federal Scientific and Technical Information, National Bureau of Standards,

U. S. Department of Commerce, Springfield, Virginia 


\section{INTERNAL: DISTRIBUTION}

Copy

No.

1-3. P. J. Hagelston

4. H. F. Carroli

5. G. B. Pleat - W. R. Workinger

6. L. Squires - M. H. Wahl

7. S. A. McNeight

8. M. H. Smith - W. H. Holstein J. B. Tinker

9. L. C. Evans - C. W. J. Wende J. W. Croach

10. W File

11. A. E. Daking

12. J. A. Monier - F. H. Endorf

13. W. P. Bebbington

14. W. R. Tyson

15. P. B. K'Burg - H. I. Butler

16. E. C. Morris - H. A. McClearen D. C. Nichols

17. PRD THE TH
SROo, Aiken, S. C.

Declassification Branch USAEC, Oak Ridge, Tenn.

Div. of Prod. USAEC Wash.

Wilmington AED

il

"

11

Engineering Department

Savannah River Plant

$"$

II

if

18. W. P. Overbeck - A. A. Johnson Savannah River Laboratory

19. J. 0. Morrison

20. J. E. Beach

21. C. H. Ice

22. C. M. Patterson

23. W. L. Marter

24. R. A. Moyer

25. G. Dessauer

26. J. W. Morris

27. W. C. Reinig

28. C. N. Wright

29. J. E. Hoy

30. W. F. Splichal, Jr.

31. TIS File Record Copy
"

II

"I

II

is

"1

II

"I

$n$

II

"1

it 

Report Number DP-1006 s c (C) Approved by Author(s) $\frac{\text { C. N. Wright, J.E. Hoy, and W. F. Splichal }}{285^{2}}$

Title Savannah River Plant Criticality Dosimetry System

Division Radiological and Environmental Sciences

Indicate known prior art

Approval (Introduction, Summary, Cover Letter)
(1) 4..tese section Director

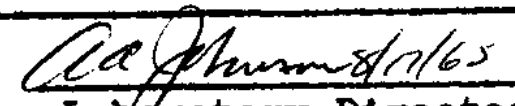

Labdratory D1rector

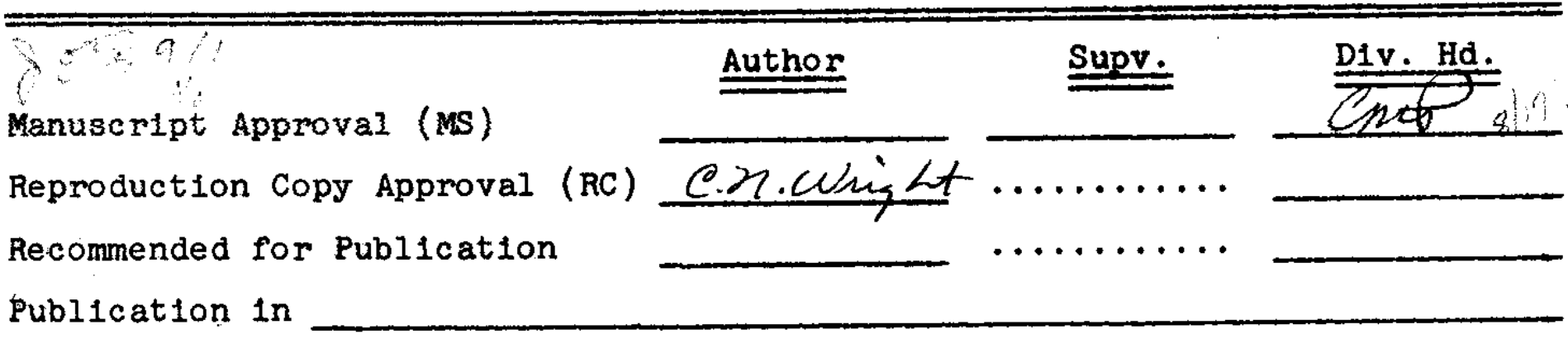

Presentation at

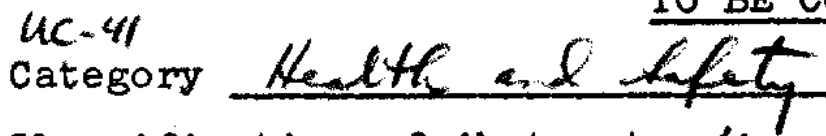
TO BE COMPLETED BY TIS Classification of Abstract Classification of Title 4

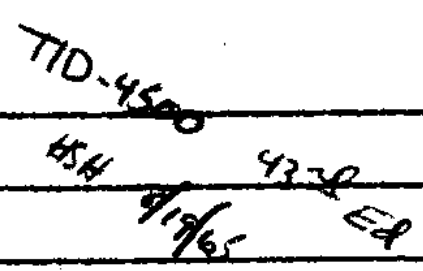

Transmittal Letter DP -1006 TL

No. of coples for Distribution

Internal

TID -4500

M-3679

Special

AECL

TOTAL
S C O

Approved by

Total Pages

Price

$$
3
$$


TECHNICAL DIVISION

SAVANNAH RTVER IABORATORY

MEMORANDUM

TO: S. W. O'REAR

FROM: J. E. BEACH $\varnothing \sum$

$$
\text { DOCUMENT REVIEW }
$$

Document :

$$
\text { Report DP-1006 }
$$

Title:

\section{Savannh atver Mant Grotearity} Dosinetry sy stecin

Author:

C. X. Wright, J. 2. Noy.

4. F. Splionnd, Ix.

Contractual Origin:

$\operatorname{AT}(07-2)-1$

Present Classiflcation:

Dnclasested

References:

No items were noted that, in my opinion, should be called to the attention of the AEC for patent consideration. 
E. I. du Pont de Nemours \& Company INCORPORATED

Mr. R. G. Erdley, Chlef

Patent Branch

Savannah River Operations office

U. S. Atomic Energy Commission

Post office Box A

Aiken, South Carolina

Dear Mr. Erdley:

\section{REQUEST FOR PATENT REVIEW}

Please review for patent matter:

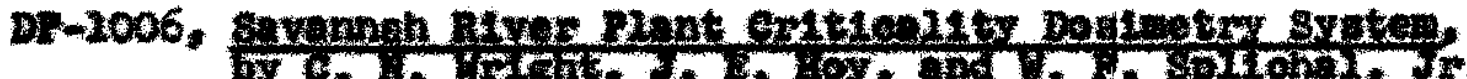

If any technical clarification is needed please call J. E. Beach whose document review is attached.

Please telephone your comments to the TIS Office (Ext. 3402) and notify me by signing and returning to TIS the original of this letter. A copy is provided for your file.

If you decide to pursue a patent on any development covered, I shall be happy to supply additional information required such as appropriate references and the names of persons responsible for the development.

The above item is approved for release.

R. G. Erdley, Chief $\overline{\text { Date }}$

Patent Branch

SROO, USAEC
Very truly yours,

C. W. J. Wende, Director

Technical Division

By:

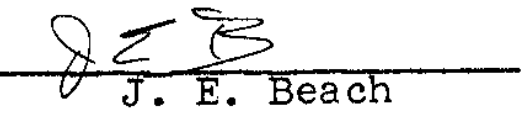


E. 1. DU Pont de Nemours \& Company

SAVANNAH RIVER LABORATORY

AIKen, SOUTH Carolina 29802

(TWX: 803.824.0018, TEL: 803.824.6331, WU: AUGUSTA, GA.)

C. W. J. WENDE, DIRECTOR TECHNICAL DIVISION - AED EXPLOSIVES DEPARTMENT

WILMINGTON
㷛
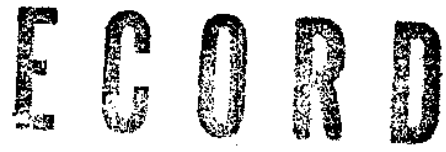

IAN 141966

$$
\begin{gathered}
\text { DP-1006, SAVANNAH RIVER PLANT CRITICALITY } \\
\text { DOSIMETRY SYSTEM }
\end{gathered}
$$

by C. N. Wright, J. E. Hoy, and W. F. Splichal, Jr.

In September 1960, the "emergency dosimetry" capab1lities of the Savannah River Plant were reported by Hoy in DP-472. This report described a criticality neutron dosimeter which was unique at that time and remains today the least expensive of several similar systems.

Last year the dosimeter and our abilities to interpret its usefulness were twice tested, utilizing the Health Physics Research Reactor at Oak Ridge National Laboratory.

The attached report updates the previous DP report, and includes in the appendix methods used in computing dose determinations. It shows the steps required - screening, preliminary dose estimates, and final dose determinations - in the event a nuclear incident involving personnel occurred.

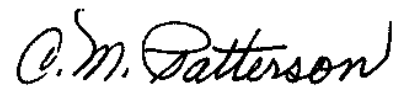

C. M. Patterson, Research Manager Radiological and Environmental Sciences Division 


\section{PRELIMINARY DISTRIBUTION}

Copy

No.

1. H. B. Rahner

2. I. A. Hobbs

3. R. G. Erdley

SROO, Aiken, S. C.

II

II

4. S. A. McNe1ght

5. I. C. Evans - C. W. J. Wende J. W. Croach

Wilmington AED

"I

6. W. R. Tyson

7. P. B. K'Burg - H. I. Butler

Savannah River Plant

8. W. P. Overbeck - A. A. Johnson J. O. Morrison

9. C. H. Ice - C. M. Patterson

10. W. C. Reinig - C. N. Wright

11. J. E. Hoy - W. F. Splichal, Jr.

12. TIS File Record Copy 


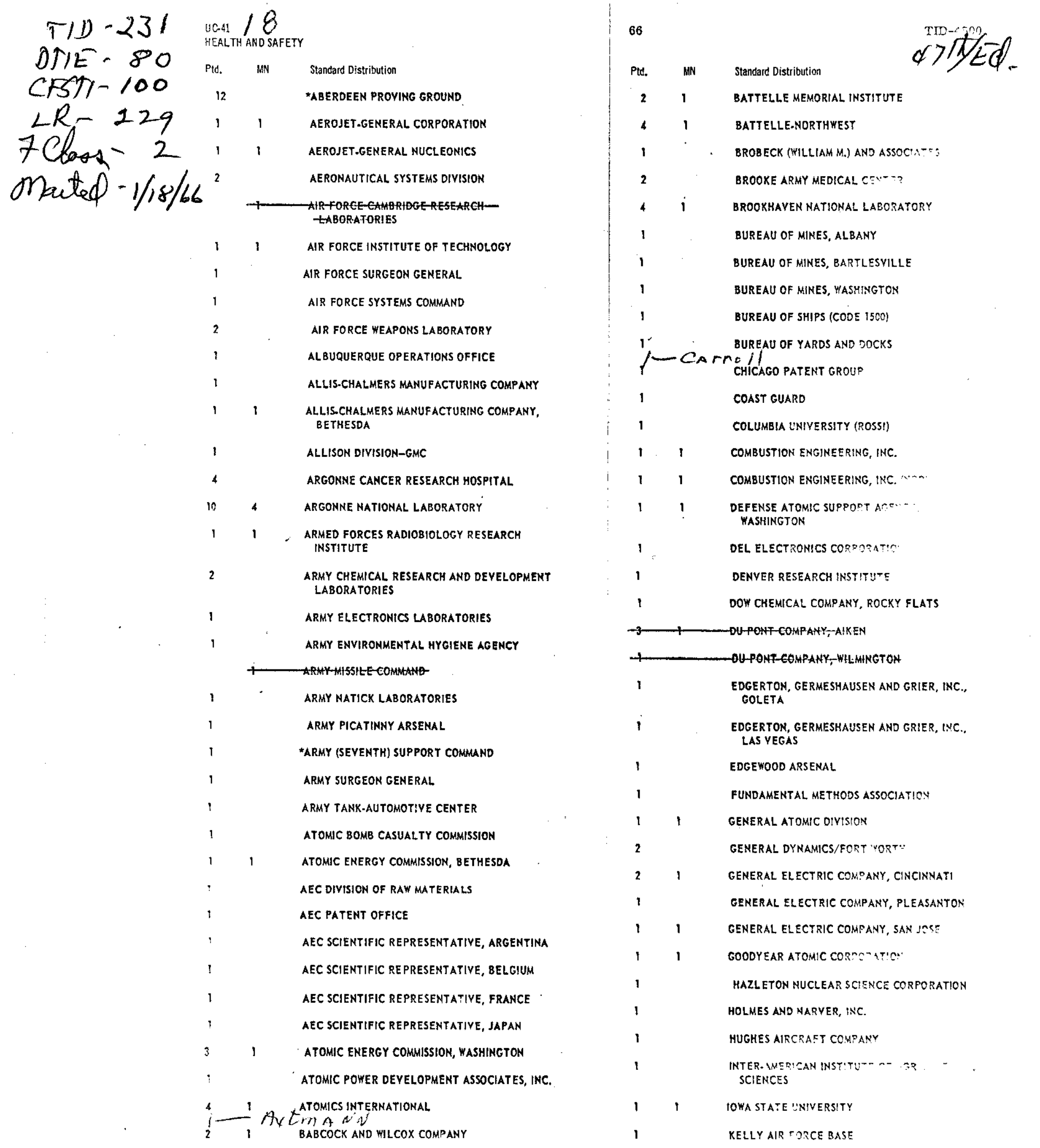




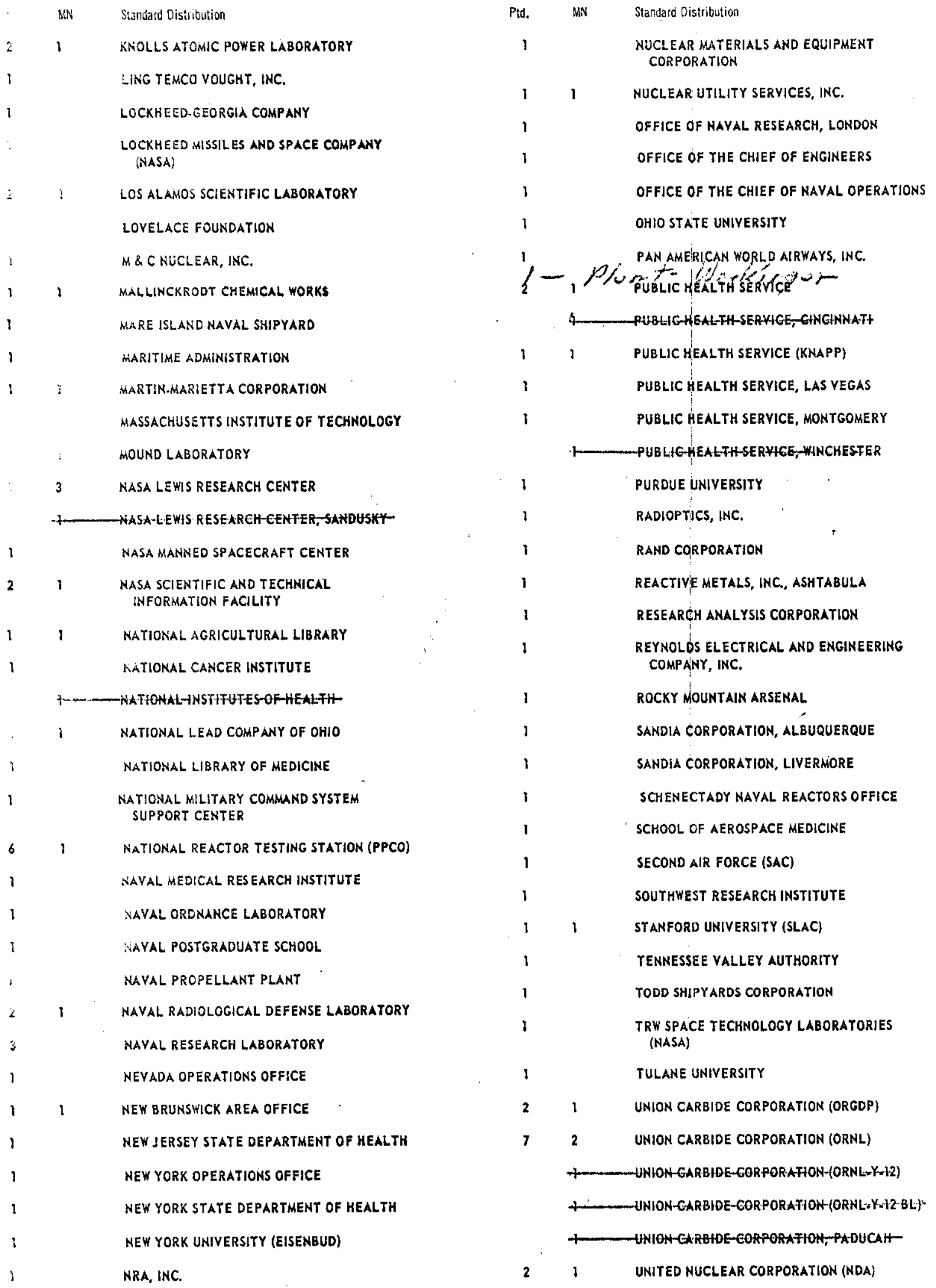


UC-41

HEALTH AND SAFETY

\begin{tabular}{|c|c|c|}
\hline Ptd. & MN & Standard Distribution \\
\hline 1 & & U. S. GEOLOGICAL SURYEY, DENYER \\
\hline$:$ & & U. S. GEOLOGICAL SURYEY, WASHINGTON \\
\hline$:$ & & U. S. WEATHER BUREAU, LAS VEGAS \\
\hline 1 & & U. S. WEATHER BUREAU, WASHINGTOM \\
\hline 4 & 1 & UNIYERSITY OF CALIFORNIA, BERKELEY \\
\hline I & & UNIVERSITY OF CALIFORNIA, DAYIS \\
\hline 2 & 1 & UNIVERSITY OF CALIFORNIA, LIVERMORE \\
\hline 1 & 1 & UNIYERSITY OF CALIFORNIA, LOS ANGELES \\
\hline 1 & & UNIVERSITY OF CALIFORNIA, SAN FRANCISCO \\
\hline 1 & & $\begin{array}{l}\text { UNIVERSITY OF CHICAGO, USAF RADIATIOH } \\
\text { LABORATORY }\end{array}$ \\
\hline 1 & & UNIVERSITY OF HAWAII \\
\hline 1 & 1 & UNIYERSITY OF PUERTO RICO \\
\hline 1 & 1 & UNIVERSITY OF ROCHESTER \\
\hline 1 & & UNIVERSITY OF TENNESSEE, MEMPHIS \\
\hline 1 & & UNIVERSITY OF TENNESSEE (UTA) \\
\hline
\end{tabular}

StandaId Olstribution
UNIVERSITY OF UTAH
UNIYERSITY OF WASHINGTON
WIRGINIA ASSOCIATED RESEARCH CENTER
WALTER REED ARMY MEDICAL CENTER
WESTERN RESERVE UNIYERSITY
WESTINGHOLSE BETTIS ATOMIC POWER
LABORATORY
WESTINGHOUSE ELECTRIC CORPORATION
WESTINGHOUSE ELECTRIC CORPORATION
(NASA)
WHITE SANDS MISSILE RANGE
DIVISION OF TECHNICAL INFORMATION
EXTENSION
1


Description of Material

No: $\quad$ DP-1006

Date: $12 / 15 / 65$

Titile: Savannah River Plant Criticality Dosimetry System

Author: C. N. Wright, J. E. Hoy, and W. F. Splichal, Jr.

Type of Material

Classified DP Report

$\square$ Classified Paper

Unclassified DP Report

X

Unclassified Paper

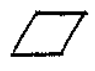

Letter

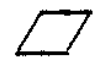

Technical Content

Approved by

/s/ C.M. Patterson Date: $8 / 17 / 65$

Classification

Approved by

Shaten

Date: $\quad 12 / 15 / 65$

S. W. O'Rear

Authority:

Topic 2.2 CG-UF-1

Topic 705.1 SROO Classification Guide

Category if DP Report

Approved by

by

$\frac{\text { Hewere }}{\text { S.W. O'R }}$

Date:

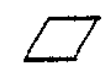$$
\text { s. Wh or Rear }
$$ 


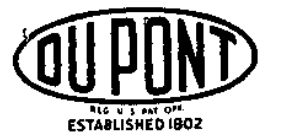

E. I. du Pont de Nemours \& Company INCORPOAATEO

SavannaH River laboratory

AIKEN, SOUTH CAROLINA 29802

(TWX: 803.824.001B, TEL: 803.824.6331, WU: AUGUSTA, GA.)
CC: I. C. Evans - C. W. J. Wende -

J. W. Croach

S. A. McNelght

W. P. Overbeck - G. Dessauer TIS FIIe

December 15, 1965

Mr. R. G. Erdley, Chief

Patent Branch

Savannah River Operations Office

U. S. Atomic Energy Commission

Post Office Box A

Aiken, South Carolina

Dear Mr. Erdley:

\section{REQUEST FOR PATENT REVIEW}

Please review for patent matter:

DP-1006, Savannah River Plant Criticality Dosimetry System, by C. N. Wright, J. E. Hoy, and W. F. Splichal, Jr.

If any technical clarification is needed please call J. E. Beach whose document review is attached.

Please telephone your comments to the TIS office (Ext. 3402) and notify me by signing and returning to TIS the original of this letter. A copy is provided for your file.

If you decide to pursue a patent on any development covered, I shall be happy to supply additional information required such as appropriate references and the names of persons responsible for the development.

The above item is approved Very truly yours,

for release.

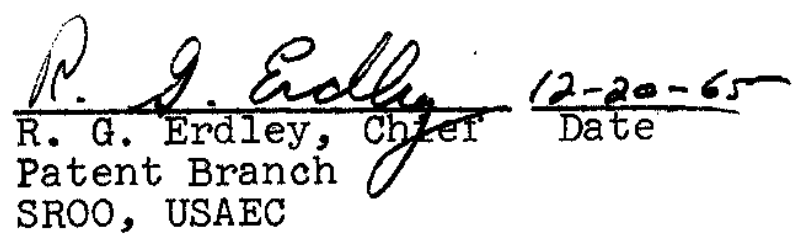

C. W. J. Wende, Director Technical Division

SROO, USAEC

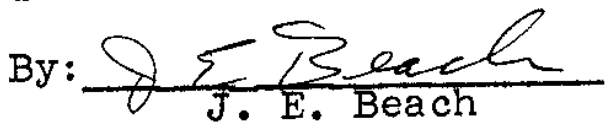


INSTRUCTIONS: This form should accompany each UNCLASSIFIED document the first time it is submitted to the

USAEC Division of Technical Information Extension, Post Office Box 62, Oak Ridge, Tennessee.

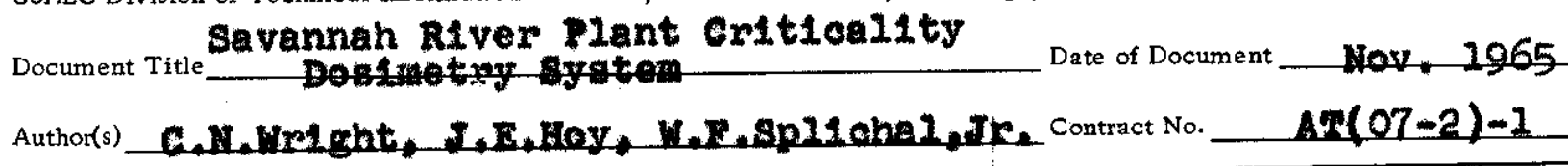

1. $x$ Research and Development Report Enclosed is a TID-4500 Standard Distribution Report as defined in AEC Manual Chapter 3202. No Journal Publication or Oral Presentation is Intended. (Use Section II or III below if Journal Publication is Intended or Section IV if Oral Presentation is Intended.)

1. XComplete TID-4500 distribution has been made, including copies to the Clearinghouse for Federal Scientific and Technical Information, National Bureau of Standards (formerly OTS) (Federal Clearinghouse sale price is \$2 2 ). The number of copies specified in TID -4500 has been forwarded to the Division of Technical Information Extension for stock and for further distribution to domestic and foreign depository libraries, foreign exchange organizations, etc., and for announcement in Nuclear Science Abstracts.

2. $\square$ Document has been printed but complete TID-4500 distribution has not been made. Copies are being furnished for the Division of Technical Information Extension to:

a. $\square$ Make complete TID-4500 distribution including copies to Federal Clearinghouse (sale price is and to depository libraries, etc.

b. $\square$ Make distribution to Federal Clearinghouse and depository libraries, etc. AEC and other Government agency distribution has been made in accordance with TID -4500 (Federal Clearinghouse sale price is $\$$ __).

c. $\square$ Other. Please specify

3. $\square$ No copies have been printed for TID -4500 and Federal Clearinghouse distribution. DTI may reproduce from copy enclosed and make TID 4500 distribution, including copies to Federal Clearinghouse for public sale, depository libraries, etc. Enclosure is: a. $\square$ Printed copy

c. $\square$ Reproducible or multilith plates (Up to 25 copies will be furnished to authors if desired. Indicate number

4. $\square$ This document, previously distributed as a classified report, has been declassified with $\square$ without $\square$ deletions. DTI may reproduce from their master copy and make TI -4500 distribution, including copies to Federal Clearinghouse for public sale, and to depository libraries, etc. (Up to 25 copies will be furnished to authors if desired. Indicate number

11. $\square$ Document Enclosed is a TID-4500 Standard Distribution Report which is also intended for Journal Publication:

TID -4500 (AEC) distribution has been made. Copies are enclosed for DTI to make single copy distribution to Federal Clearinghouse and to the domestic depository libraries, and for announcement in NSA.

2. $\square$ Copies are being furnished DTI to make TID-4500 (AEC) distribution, and single copy distribution to Federal Clearinghouse and to the domestic depository libraries, and for announcement in NSA.

3. $\square$ From the copy enclosed, DTI is requested to reproduce in Microcard form and make TID-4500 (AEC) distribution, domestic depository library distribution and send 1 full size copy to Federal Clearinghouse, and announce in NSA.

Document enclosed has or will be submitted for publication in the following scientific journal:

111. $\square$ Document enclosed is intended for publication in a journal, whose publication policy precludes advance distribution within the AEC and single copy distribution to Federal Clearinghouse and to domestic depository libraries.

1. Paper has been or will be submitted for publication in the following scientific journal:

(NOTE: DTI will hold this document for internal use and will not announce in NSA. No further distribution will be made except in unique circumstances when the report is required by present work of another AEC Contractor in advance of the paper's appearance in the journal. Such further distribution by DTI will be limited to specific requests for this information.) 
IV. $\square$ Document enclosed is intended for Oral Presentation.

Name, Location, Sponsor of Meeting

Publication plans are:

Date

1. $\square$ This paper will be included in the published proceedings of the meeting.

2. $\square$ This paper will not be included in published proceedings. After the date

a. $\square$ DTI is requested to reproduce and proceedings. After the date indicated above:

libraries and announce in NSA.

b. $\square$ We (originator) will mak

please transmit copies to DTI with a distribution, including copies to Federal Clearinghouse. (Note: When printed,

c. $\square$ Paper will be submitted for joumal publication appropriately checkęd in Section I.)

submit to DTI a new PRF appropriately checked in either Section II or tII.)

\section{V. $\square$ Document enclosed is an internal or informal report not intended for TID-4500 Standard Distribution,
Journal Publication or Oral Presentation.} AEC Manual Chapter 3202 requires that informal reports generally be given TID -4500 distribution, and that technical information
contained in internal reports also appe ar in a distributable document which receives appropriate distribution.

internal reports (subsequently distributed externally) under certain cocommend distribution limitations for informal reports and originator, or DTI and the cognizant AEC Program Division if distribution. It also provides for negotiation between DTI and the to Federal Clearinghouse. Recommendations are:

1. DTI is $\square$ is not $\square$ to make selected positive distribution to certain AEC contractors as appropriate.

3. DTI is $\square$ is not $\square$ to fill requests for this document from AEC contractors.

4. DTI is $\square$ is not $\square$ to make a single copy and fill requests for this document from other Government agencies.

IF DISTRIBUTION LIMTTATIONS ARE INDICATED ABOVE

CHAPTER 3202.

Patent clearance for the document cited in this Publication Release Form has $\bar{x}$ has not $\square$ been obtained.

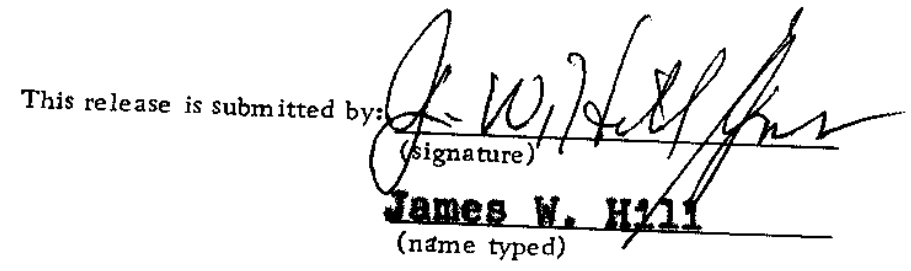

Organization Savannah River Laboratory

Date 1 Ir -66

If it is desired that correspondence concerning this document be directed to an individual other than the name above,
ple ase indicate 


\section{SAVANNAH RIVER PLANT CRITICALITY DOSIMETRY SYSTEM}

by

Charles N. Wright

John E. Hoy

W1lliam F. Splichal, Jr.

Approved by

C. M. Patterson, Research Manager

Radiological and Environmental Sciences Division

November 1965

E. I. DU PONT DE NEMOURS \& COMPANY

SAVANNAH RIVER LABORATORY

AIKEN, SOUTH CAROLINA

CONTRACT AT(07.2)-1 WITH THE

UNITED STATES ATOMIC ENERGY COMMISSION 


\begin{abstract}
Fissionable materials are handled and processed at the Savannah River Plant. Although the probability of an accidental criticality occurring is small, the possibility must be considered. This report describes the methods which would be used to segregate exposed and nonexposed personnel and to determine neutron and gamma doses recelved by those who were exposed.
\end{abstract}




\section{CONTENTS}

Page

List of Tables and Figures . . . . . . . . . . . . . . . . . IV

Introduction . . . . . . . . . . . . . . . . . . . . . . 1

Summary . . . . . . . . . . . . . . . . . . . . . . . . . . 11

Discussion . . . . . . . . . . . . . . . . . . . . . . . . . 2

Screening . . . . . . . . . . . . . . . . . . . . . . . 2

Preliminary Dose Estimates . . . . . . . . • . . . . . . 2

Final Dose Determination . . . . . . . . . . . . . 5

Description of Dosimeter . . . . . . . . . . . . . . . . 5

Assessment of Neutron Fluence . . . . . . . . . . . . . 6

Energy Intervals of $0.0 \mathrm{eV}$ to $0.5 \mathrm{eV}$, and $0.5 \mathrm{eV}$ to $2 \mathrm{eV} .7$

Energy Intervals of $2 \mathrm{eV}$ to $1 \mathrm{MeV}$. . . . . . . . . . 7

Energy Interval of I MeV to $2.9 \mathrm{MeV}$. . . . . . . . . . 8

Energy Interval above $2.9 \mathrm{MeV}$. . . . . . . . . 8

Orientation of Dosimeter . . . . . . . . . . . . . . 8

Determination of Neutron Dose . . . . . . . . . . . . 9

Gamma Dose . . . . . . . . . . . . . . . . . . 10

Tests of Dosimeter . . . . . . . . . . . . . . . 11

Bibliography . . . . . . . . . . . . . . . . . . . . 14

Appendix I - Manual Calculation of CND Results . . . . • • . 15

Appendix II - Fortran Program for Computation of Dose from

CND Data... . . . . . . . . . . . . . 20 


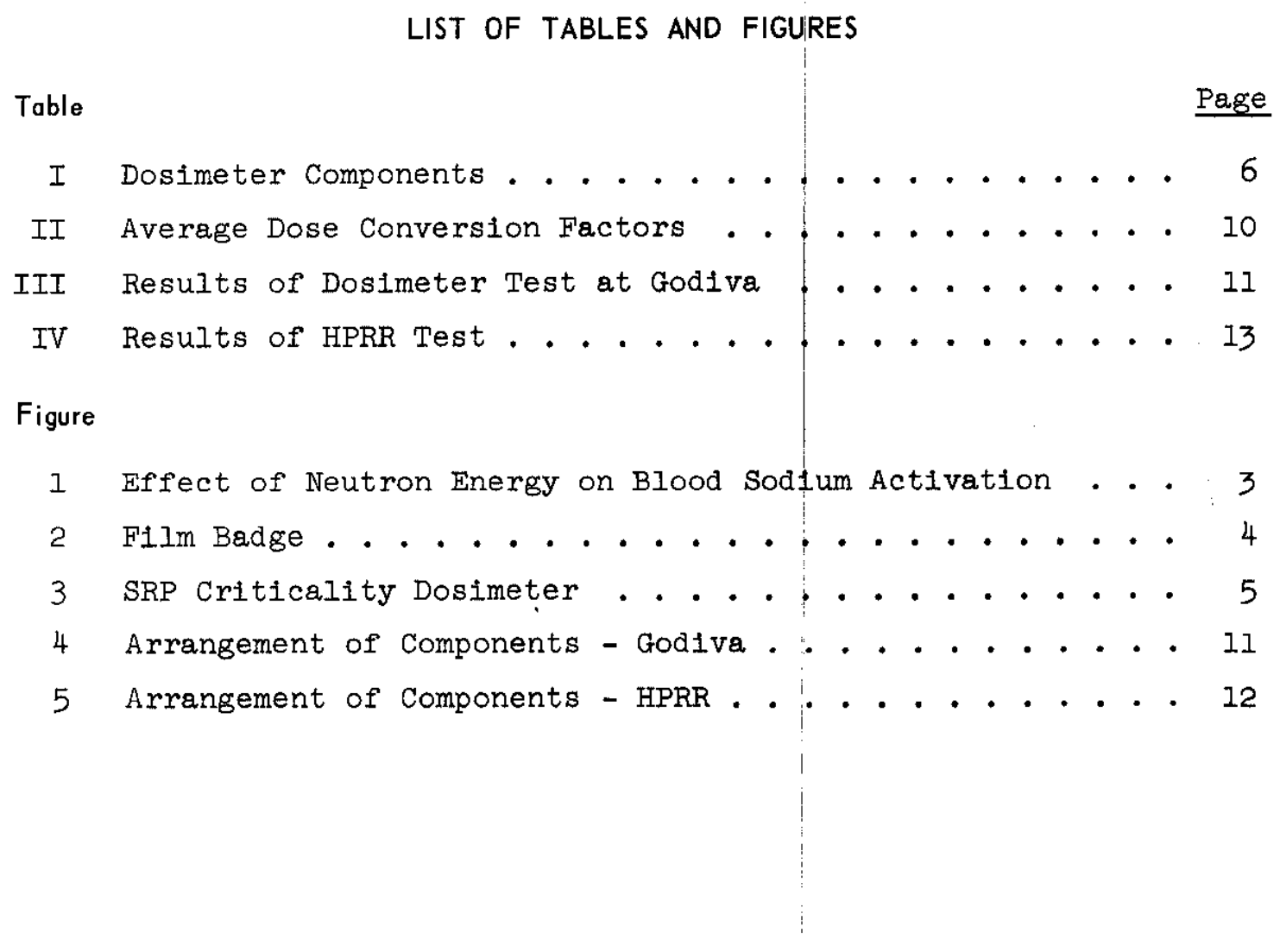




\title{
SAVANNAH RIVER PLANT CRITICALITY DOSIMETRY SYSTEM
}

\author{
INTRODUCTION
}

At any location where fissionable materials are processed, the possibility of a criticality accident must be considered. In the event of such an accident, it is desirable that the radiation dose received by personnel be quickly determined.

The Savannah River Plant (SRP) system of dosimetry for use after a criticality accident may be considered in three phases. The first is separation of exposed and unexposed personnel immediately after the accident. Indium folls in the film dosimeter and ldentification badge would be activated by neutron exposure and provide an indicator of exposed personnel. In the second phase, a preliminary estimate of neutron dose would be made by measurement of the ${ }^{24} \mathrm{Na}$ activation in the blood and body of exposed persons; the gamma dose would be indicated from film dosimeter results.

For the final phase, a more precise determination of dose would be made. This determination requires a simple, dependable dosimeter that could be worn by all employees working with fissionable material. In addition, the dosimeter would give accurate indications over a wide range of neutron and gamma doses, be lightwelght, small, and convenient to wear. (Dosimeters that are mounted in fixed positions in work areas may be difficult to recover after an accident, and errors in interpretation of dose may arise because these instruments are at different

locations from the exposed personnel.) The criticality neutron dosimeter (CND) was designed so that only one dosimeter would be required to determine the total dose to the wearer. Low cost was a design objectlve because several hundred units are required.

This report describes the techniques and instruments for the three phases of dosimetry. Emphasis is placed on the more exact measurements that are made with the criticality neutron dosimeter.

\section{SUMMARY}

In the event of a criticality accident at SRP, the radiation doses recelved by personnel involved would be determined by use of indium folls in the identification badges and film dosimeters, from blood sodium activation, and from analysis of the SRP Criticality Neutron Dosimeter (CND). The CND contains cadmium-shielded and unshlelded indium folis, a copper foil, sulfur powder, sodium fluoride powder, and thermoluminescent dosimeters (TLD). 
From determination of induced radioactivity in the foils and powders, the neutron fluence in five energy intervals may be determined. By comparing activity induced in the sodium fluoride with the activity induced in the blood of the wearer, the direction from which he was exposed may be estimated. The TID's enable measurement of gamma exposure between $I R$ and $10^{5} \mathrm{R}$.

Appendices describe both manual and computer methods used in procesing the data obtained.

\section{DISCUSSION}

\section{SCREENING}

A basic requirement of a criticality dosimetry system is the ability to screen quickly a large number of persons, in order to segregate the exposed and unexposed individuals. At SRP this screening ability is provided by 0.005 -inch-thick indium folls in the identification badges and film dosimeters. The foll in the ldentification badge is approximately $I / 2-i n c h$ square. After activation, it will cause a response of at least $100 \mathrm{c} / \mathrm{m}$ on a GM survey instrument (when placed one centimeter from the wall of the GM tube) for every Rad of neutron exposure. The foll in the film badge has four times the area of that in the identification badge with a corresponding increase in sensitivity. Because it is almost impossible that a criticality accident at SRP will involve persons not wearing an identification badge, and highly unlikely that persons not wearing a film badge would be exposed, the health physiclst is able to quickly segregate exposed and unexposed persons. No dose estimates are made from the GM instrument readings.

\section{PRELIMINARY DOSE ESTIMATES}

A rough estimate $( \pm 100 \%)$ of the neutron dose received can be made by placing the probe of a GM survey instrument against the abdomen of a person, having him bend at the waist, and using the following equation:

$$
\text { Dose }(\text { Rads })=\frac{2 \times c p m}{\text { body wt in Ib }}
$$

where cpm is the count rate per minute (corrected for decay to time of incident) from activation of sodium in the body. Estimates by this method may be pessimistic because short-lived ${ }^{38} \mathrm{Cl}$ is also a product of neutron activation of body elements. Persons determined by these screening methods to have been exposed are checked for contamination, decontaminated if necessary (unless badly injured), and placed under 
medical care. A $50 \mathrm{ml}$ sample of blood is obtained from each of these people for further analysis before any sodium is administered, either through food or medical treatment. Ammonium oxalate is added to the sample to prevent coagulation. The blood is centrifuged and a $10 \mathrm{ml}$ sample of plasma is decanted into a standard culture tube (15 mm x $125 \mathrm{~mm})$. The tube is placed horlzontally on a $3^{\prime \prime} \times 3^{\prime \prime}$ sodium lodide scintillation counter, and the gamma ray activity between 2.6 and 3.0 $\mathrm{MeV}$ is determined. This energy interval is chosen to avoid interference from ${ }^{38} \mathrm{Cl}$.

Test exposures to neutron spectra, ranging from an unmoderated fission spectrum at the ORNL Health Physics Research Reactor (HPRR)(1) to a thermal spectrum at the Standard Pile (SP) reactor at the Savannah River Plant, (2) have provided factors for converting ${ }^{24} \mathrm{Na}$ activity in blood plasma to a Rad dose (Figure 1). For first estimates of dose, an assumption of the neutron spectrum must be made from knowledge of the type of critical assembly involved. The broad characterizations used are "Fast," "Semimoderated," and "Thermal." Conversion factors used for these cases are:

Fast

$1.65 \times 10^{5} \mathrm{Rad} / \mu \mathrm{c} / \mathrm{cc}$

Semimoderated

$1.00 \times 10^{5} \mathrm{Rad} / \mu \mathrm{c} / \mathrm{cc}$

The rmal

$0.75 \times 10^{5} \mathrm{Rad} / \mu \mathrm{c} / \mathrm{cc}$

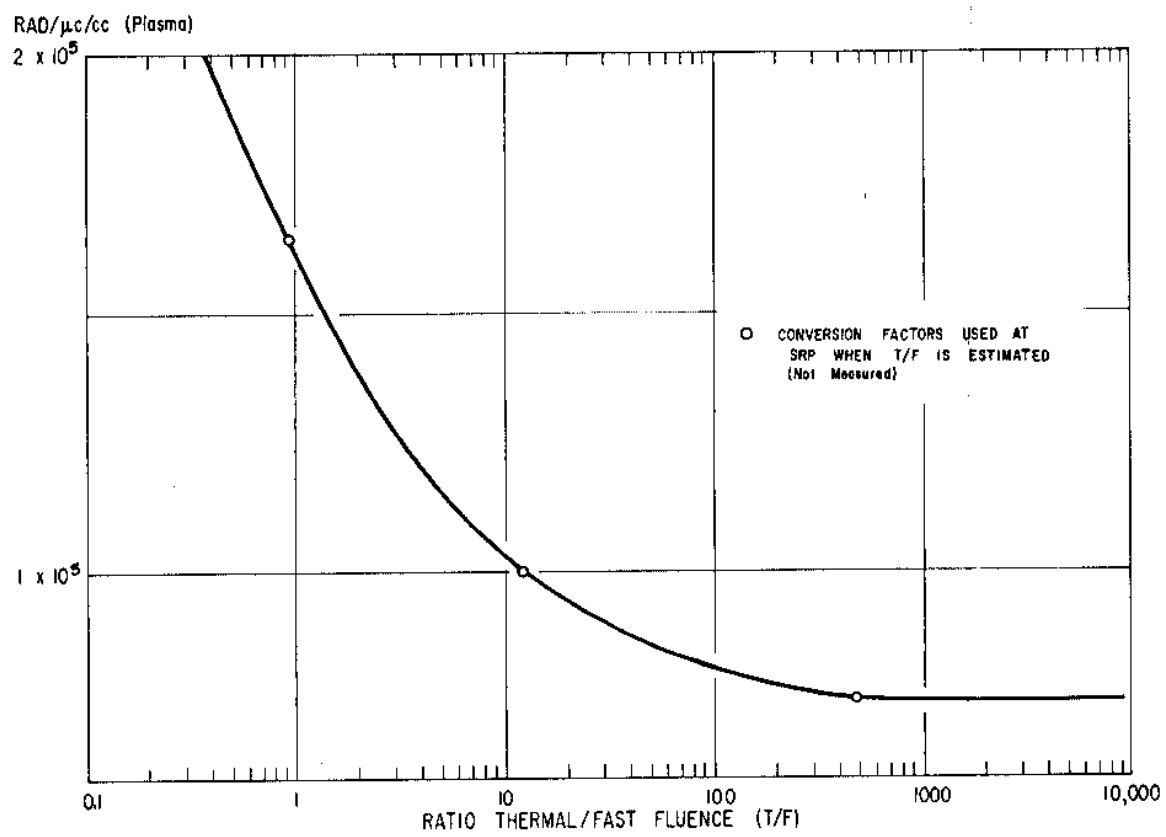

FIG. I EFFECT OF NEUTRON ENERGY ON BLOOD SODIUM ACTIVATION 
After the CND is processed, a better definition of the spectrum will be available and the dose estimate can be refined.

Preliminary gamma dose measurements are obtained from the film dosimeter. The front face, containing the indium foil is removed from the film badge (Figure 2) as soon as practicable after the accident so that the film will not be exposed excessively by the indium. The film from the badge is pencil-marked in the darkroom to retain identity, in case the X-rayed identification has been obliterated by the exposure, and then is processed normally. Because of silver activation and other neutron effects, the indicated gamma reading may be high. Experimental data Indicate that Du Pont type 1290 dosimeter film is not more than 7 percent sensitive to fast neutrons. (If the film is exposed to 100 Rad of fast neutrons, the indicated gamma reading will be not more than 7 Rad. )

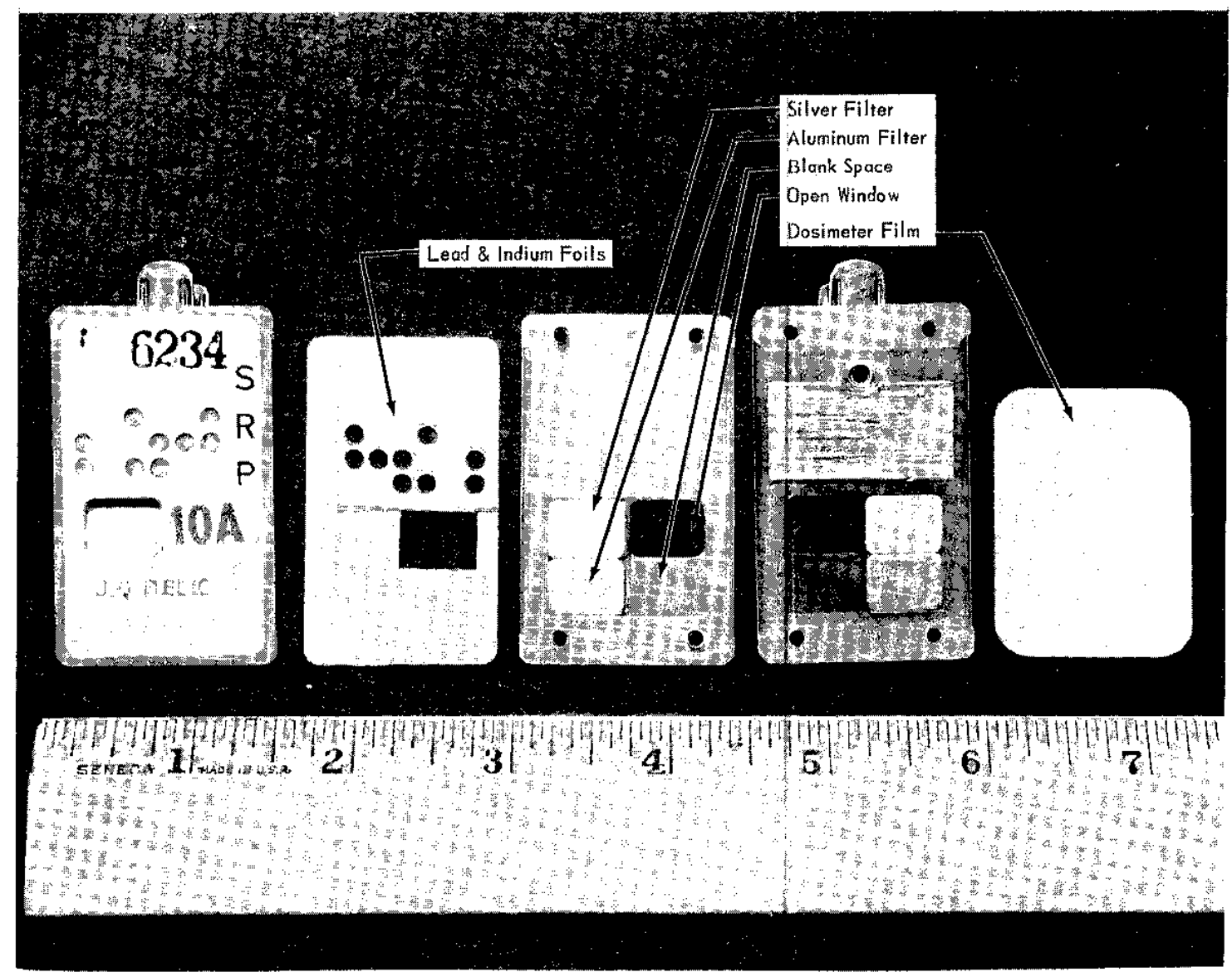

DPSPF $-6341-1$

FIG. 2 FILM BADGE 


\section{FINAL DOSE DETERMINATION}

The most accurate determination of dose recelved would be made from the evaluation of the components contained in the Criticality Neutron Dosimeter.

\section{DESCRIPTION OF DOSIMETER}

The original model of the dosimeter and its early development were described by Hoy $(3)$ in 1960. A diagram of the current model dosimeter is given in Figure 3. The components are housed in a "Mylar"* tube, 4-1/2 inches long and $1 / 2$ inch in diameter, with a pocket clip attached. Indium, copper, and cadmium folls are shaped into hollow cylinders to reduce directional effects. These folls, and specific amounts of sodium fluoride and sulfur, are contalned in three small polystyrene vials.

* Du Pont trademark for polyester film.

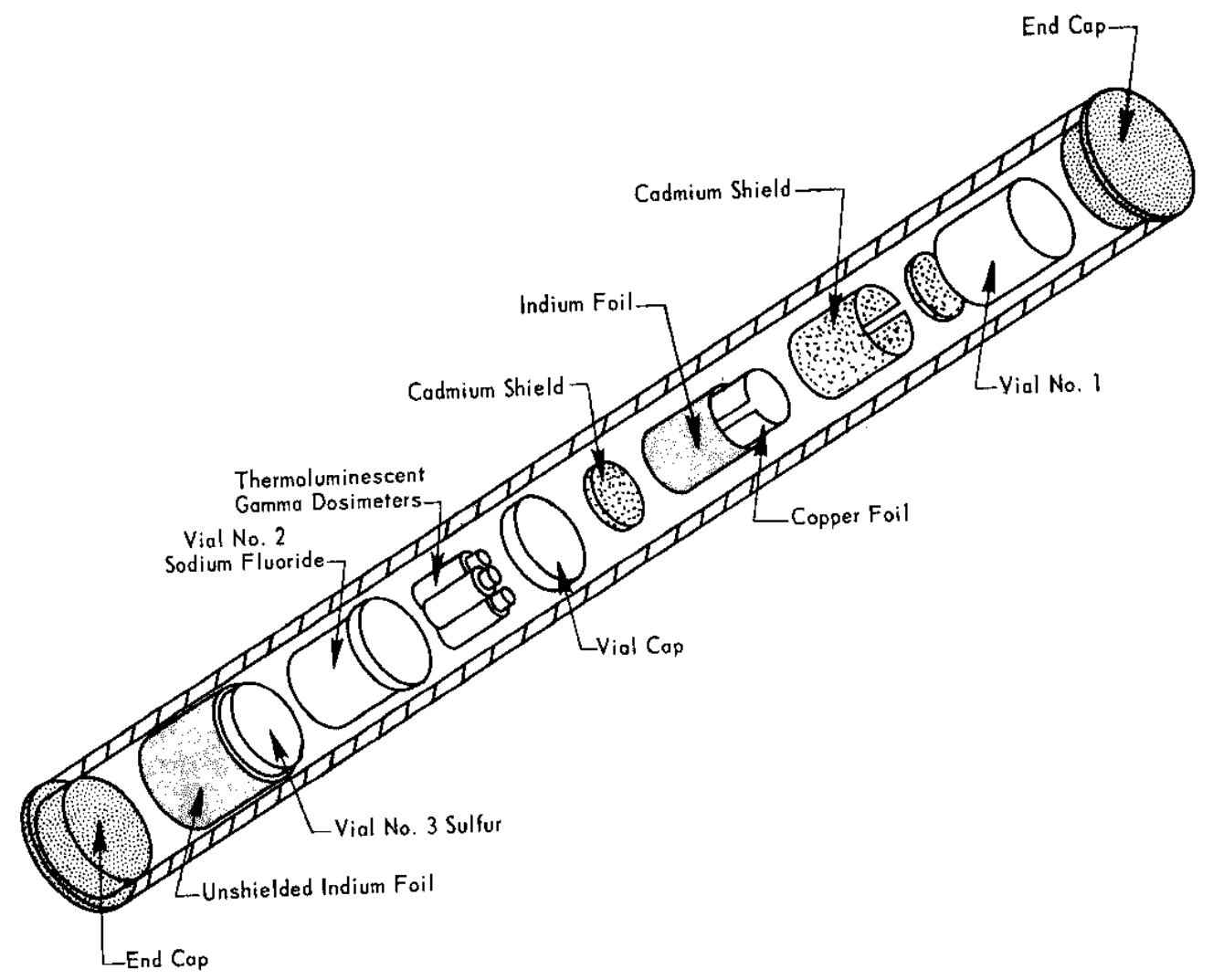

FIG. 3 SRP CRITICALITY DOSIMETER 
To expedite processing of the components after an accident, all activation materials are preweighed; the exact weights are listed in each dosimeter during assembly. The thermoluminescent lithium fluoride powder is contained in three smaller polyethylene vials. Table I. describes the components. Cost of the dosimeter is approximately \$15.

\section{TABLE I}

Dosimeter Components

\begin{tabular}{ll}
\multicolumn{1}{c}{ Material } & \multicolumn{1}{c}{ Size or Weight } \\
\hline Cadmium (3 pieces) & $1^{\prime \prime} \times 5 / 8^{\prime \prime} \times 1 / 32^{\prime \prime}$ \\
& $3 / 8^{\prime \prime}$ diameter $\times 1 / 32^{\prime \prime}$ (2 pieces) \\
Indium (2 pieces) & $15 / 16^{\prime \prime} \times 5 / 8^{\prime \prime} \times 0.005^{\prime \prime}$ \\
& $1-7 / 16^{\prime \prime} \times 5 / 8^{\prime \prime} \times 0.005^{\prime \prime}$ \\
Copper & $15 / 16^{\prime \prime} \times 5 / 8^{\prime \prime} \times 0.005^{\prime \prime}$ \\
Sulfur & 1.00 gram \\
Sodium fluoride & 1.50 grams \\
Lithium fluoride & $40 \mathrm{mg}$ per vial
\end{tabular}

\section{ASSESSMENT OF NEUTRON FLUENCE}

The dosimeter measures the neutron fluence (time-integrated flux density) in five energy intervals across the fission neutron spectrum. Evaluation of fluence is based on activation of indlum, copper, and sulfur. These were selected primarily because they have useful activation cross-section characteristics over a desired range of neutron energies. The neutron fluence, $\mathrm{n} / \mathrm{cm}^{2}$, in each energy range is obtained from the following expression:

$$
\mathrm{n} / \mathrm{cm}^{2}=\frac{\mathrm{d} / \mathrm{s}}{\sigma_{\text {act }} \mathrm{NG \lambda e^{- \lambda t }}}
$$

where, $N=$ the number of nuclei with an activation cross section, $\sigma_{\text {act }}$

$\mathrm{G}=\mathrm{a}$ constant to correct the observed counting rate, $\mathrm{d} / \mathrm{s}$, to the absolute disintegration rate of the target material

$t=$ the elapsed time in seconds between exposure and counting.

This equation assumes that exposure was short, because a criticality alarm system causes immediate evacuation of personnel from work areas. An average activation cross-section is assigned to each energy interval. 
All folis and powders are counted in a lead-shielded $\beta-\gamma$ GM Counter, for which a $\mathrm{Ra} D \& E$ conversion factor has been obtalned. The GM tube is an end-window type with a window thickness of $\sim 2 \mathrm{mg} / \mathrm{cm}^{2}$. All folls are centered on the planchet with the outside surface facing the tube window. Powders are evenly spread over the surface of the planchet before counting.

Energy Intervals of $0.0 \mathrm{eV}$ to $0.5 \mathrm{eV}$, and $0.5 \mathrm{eV}$ to $2 \mathrm{eV}$

Bare and cadmium-shielded indium folls are used to determine neutron fluence in these energy intervals. Indium has two stable isotopes: ${ }^{113} \mathrm{In}$ (4.28\% abundance) and ${ }^{115} \mathrm{In}$ (95.72\% abundance). ${ }^{115} \mathrm{In}(\mathrm{n}, \gamma){ }^{116} \mathrm{In}$ Is the reaction of interest. ${ }^{118} \mathrm{In}$ has three isomers, two of which have very short half-lives (2 seconds and 14 seconds); the third isomer, with a 54-minute half-life, is the principal source of radioactivity for a few hours after neutron irradiation. ${ }^{114} \mathrm{In}$, resulting from the ${ }^{113} \mathrm{In}(\mathrm{n}, \gamma)$ ${ }^{114}$ In reaction, has an isomer with a 50-day half-life which is useful when a considerable delay occurs before counting.

The cross section of indlum approximates a $1 / \mathrm{v}$ relationship from $0.025 \mathrm{eV}$ to $0.3 \mathrm{eV}$, that is, the cross section decreases as neutron velocity increases. Above $0.3 \mathrm{eV}$, resonances occur, with the principal peak at $1.4 \mathrm{eV}$.

Cadmium of the thickness used in the dosimeter ( 0.03 inch) absorbs essentially all neutrons with energies less than $0.5 \mathrm{eV}$, the cadmium cutoff. Therefore, the difference between the activities of the bare and the cadmium-shielded indium folls is caused by neutrons in the energy interval from $0.0 \mathrm{eV}$ to $0.5 \mathrm{eV}$. A factor of 1.15 is used to correct for the resonant absorption of neutrons by the cadmium shield. (4) The effective activation cross section for this interval is 145 barns. Activation of cadmium-shielded indium is used to measure the fluence in the energy interval from $0.5 \mathrm{eV}$ to $2 \mathrm{eV}$. A resonance integral (corrected for flux depression) of 650 barns is assigned to this interval.

\section{Energy Interval of $2 \mathrm{eV}$ to $1 \mathrm{MeV}$}

The reaction of interest for this energy interval is ${ }^{83} \mathrm{Cu}(n, \gamma)$ ${ }^{64} \mathrm{Cu}$. ${ }^{64} \mathrm{Cu}$ has a 12.8 -hour half-life. A competing activity resulting from ${ }^{8} \mathrm{Cu}$ (5-minute half-life) can be minimized by counting the copper no sooner than 1 hour after irradiation. The average activation cross section for ${ }^{83} \mathrm{Cu}$ in this energy range is 0.300 barn. (5) Above $1 \mathrm{MeV}$ the inelastic neutron scattering cross section becomes dominant. The copper is shielded by indium and cadmium to minimize the effect of neutrons below $2 \mathrm{eV}$. 
Energy Interval of $1 \mathrm{MeV}$ to $2.9 \mathrm{MeV}$

The inelastic scattering reaction of fast neutrons with ${ }^{115}$ In is used to determine fluence above $1 \mathrm{MeV}$. While the threshold for this reaction is about $450 \mathrm{keV}$, its cross section becomes significant at I. MeV. The average cross section above $I \mathrm{MeV}$ is 0.180 barn. The $115 \mathrm{~m}_{\text {In }}$ isomer has a 4.5-hour half-life. Gamma spectrometric analysis is used to distinguish the activation due to the inelastic reaction from the activation by the epithermal neutrons. The cadmium-shielded indium foil is used for this measurement.

The cross section for this reaction remains significant to values above $5 \mathrm{MeV}$. Therefore, the fluence of neutrons above $2.9 \mathrm{MeV}$, as determined from the activation of sulfur, must be subtracted from the fluence calculated from indium activation. The difference represents the fluence in the range from $1 \mathrm{MeV}$ to $2.9 \mathrm{Mev}$.

\section{Energy Interval above $2.9 \mathrm{MeV}$}

The threshold reaction, ${ }^{32} S(n, p){ }^{32} p$, is used to measure fluence above $2.9 \mathrm{MeV}$. Sulfur has a relatively high and constant cross section, and ${ }^{32} \mathrm{P}$ has a conveniently long half-life.

\section{ORIENTATION OF DOSIMETER}

Since the dosimeter is worn on the front of a person and the activation of the dosimeter is affected by the body's moderation and shielding, it is necessary to determine whether or not the wearer faced the neutron source in order to correct the fluence values. The correction is made by comparing the ${ }^{24} \mathrm{Na}$ in the wearer's blood with that in the sodium fluoride of the dosimeter. Blood sodium activation is relatively independent of body orientation to the source but is influenced by the energy of the neutrons. Activation of the sodium in the dosimeter is affected by both the body orientation and the neutron spectrum.

To determine the relationship between the activation of the sodium (in the dosimeter and blood), the neutron energy, and the orientation of the dosimeter, polyethylene phantoms were exposed to neutrons from a graphite-moderated reactor and an unmoderated critical assembly. The phantoms contained sodium chloride solution of the same concentration as In human blood. Dosimeters were attached to the front (surface facing the source), side, and back of the phantom. From these experiments, the following relationships were empirically established: 
Case 1. When the source is to the side of the wearer

$\mathrm{Y}=\frac{{ }^{24} \mathrm{Na} \text { per gram of sodium in } \mathrm{NaF}}{{ }^{24} \mathrm{Na} \text { per gram of sodium in blood }}=0.14\left[\frac{\text { thermal fluence }}{\text { fast fluence }}\right]^{0.61}$, where

the thermal fluence and the fast fluence (greater than $2.9 \mathrm{MeV}$ ) were

those values determined by the dosimeter (uncorrected for direction).

Case 2. When the wearer is facing the source

$$
\frac{{ }^{24} \mathrm{Na} \text { per gram of sodium in } \mathrm{NaF}}{{ }^{24} \mathrm{Na} \text { per gram of sodium in blood }}>\mathrm{Y}+0.3 \mathrm{Y}
$$

Case 3. When the wearer is facing away from the source

$$
\frac{{ }^{24} \mathrm{Na} \text { per gram of sodium in } \mathrm{NaF}}{{ }^{24} \mathrm{Na} \text { per gram of sodium in blood }}<\mathrm{Y}-0.3 \mathrm{Y}
$$

The following factors are used to correct the fluence for the effects of body moderation and shielding.

$\begin{array}{lcccc}\text { Energy Range } & \begin{array}{c}\text { Side } \\ \text { Exposure }\end{array} & \begin{array}{c}\text { Wearer } \\ \text { Facing Source }\end{array} & \begin{array}{c}\text { Wearer Facing } \\ \text { Away from Source }\end{array} \\ 0.0 \mathrm{eV}-0.5 \mathrm{eV} & 1 & 1 & 0.23 & 0.64 \\ 0.5 \mathrm{eV}-2 \mathrm{eV} & 1 & 0.35 & 1.6 \\ 2 \mathrm{eV}-1 \mathrm{MeV} & 1 & 0.45 & 2.0 \\ 1 \mathrm{MeV}-2.9 \mathrm{MeV} & 1 & 0.79 & 5.4 \\ \text { Above } 2.9 \mathrm{MeV} & 1 & 0.72 & 6.7\end{array}$

\section{DETERMINATION OF NEUTRON DOSE}

The dose equivalent is the product of absorbed dose (Rad), quality factor, dose distribution factor, and other modifying factors. The quality factor for criticality neutron exposures has not been established. For this reason the neutron dose is given in Rads.

$$
\text { Snyder's }(s) \text { calculations were used to determine the tissue dose }
$$
at a $5 \mathrm{~cm}$ depth, the depth of blood-forming organs. From these calculations, the relationship between $\operatorname{Rad} /(\mathrm{n})\left(\mathrm{cm}^{2}\right)$ and neutron energy was 
established. An average dose conversion factor was selected for each neutron energy interval (Table II).

\section{TABLE II}

Average Dose Conversion Factors

$\begin{array}{ll}\text { Energy Interval } & \frac{\operatorname{Rad} /(\mathrm{n})\left(\mathrm{cm}^{2}\right)}{0.16 \times 10^{-9}} \\ \text { Thermal to } 0.5 \mathrm{eV} & 0.22 \times 10^{-\theta} \\ 0.5 \mathrm{eV} \text { to } 2.0 \mathrm{eV} & 1.25 \times 10^{-\theta} \\ 2.0 \mathrm{eV} \text { to } 1 \mathrm{MeV} & 2.87 \times 10^{-\theta} \\ 1 \mathrm{MeV} \text { to } 2.9 \mathrm{MeV} & 4.80 \times 10^{-9}\end{array}$

Manual calculation of the dose is lengthy and involved (see Appendix I); however, an electronic computer program which accepts counting data, decay and exposure times, and weights of activated materials is avaliable (see Appendix II). The computer calculates the orientation of the dosimeter, fluence and dose in the five energy intervals, and total dose.

If a dose value other than that at $5 \mathrm{~cm}$ depth is desired, suitable factors for converting fluence to dose for each spectrum segment may be applied to the fluence values which are obtalned.

\section{GAMMA DOSE}

Lithium fluoride is used to measure the gamma dose from $25 \mathrm{mR}$ to $10^{\circ} \mathrm{R}$. Three polyethylene vials, each containing $40 \mathrm{mg}$ of LiF, are included in the dosimeter. One of the LiF vials is used to establish the correct range setting for the electronic reader, and the other two vials are used for duplicate dose measurements. LiF, enriched to $99.91 \%$ ${ }^{7} \mathrm{~L} 1$, is relatively insensitive to neutrons. A 100 Rad neutron dose, primarily fast neutrons, resulted in an apparent gamma dose of $7 \mathrm{R}$.

Gamma dose results are corrected for the direction of exposure as follows:

$$
\begin{array}{ll}
\text { Front Exposure } 0.7 \\
\text { Side Exposure } & 1.0 \\
\text { Back Exposure } 2.1
\end{array}
$$




\section{Tests of Dosimeter}

Several tests of the dosimetry system have been made to determine the quality of performance. The first of the tests was made at fros Alamos using the Godiva critical assembly as the neutron source. In this test, pairs of dosimeters were mounted on the outside of a $6-1 / 2$ galion cylindrical polyethylene container filled with an aqueous solution of sodium chloride having the same sodium concentration as human blood. Arrangement of the components around the Godiva assembly is shown In Figure 4. Data in Table III indicate that the maximum deviation of the dosimeter from the calculated neutron doses was $12 \%$, with an average deviation of $6.8 \%$. The orientation or position of the dosimeter was correctly calculated for over $80 \%$ of the dosimeters.

\section{TABLE III}

\section{Results of Dosimeter Test at Godiva ${ }^{(a)}$}

\begin{tabular}{|c|c|c|}
\hline $\begin{array}{l}\text { Position } \\
\text { on Phantom }\end{array}$ & $\begin{array}{c}\text { Computer } \\
\text { Calculated } \\
\text { Position } \\
\end{array}$ & $\begin{array}{l}\text { Dosimeter Results } \\
\text { (Neutron Dose), Rad }\end{array}$ \\
\hline $\begin{array}{l}\text { Front } \\
\text { Front }\end{array}$ & $\begin{array}{l}\text { Front } \\
\text { Front }\end{array}$ & $\begin{array}{l}659 \\
683\end{array}$ \\
\hline $\begin{array}{l}\text { S1de } \\
\text { Side }\end{array}$ & $\begin{array}{l}\text { Side } \\
\text { Front }\end{array}$ & $\begin{array}{l}759 \\
747\end{array}$ \\
\hline $\begin{array}{l}\text { Back } \\
\text { Back }\end{array}$ & $\begin{array}{l}\text { Back } \\
\text { Back }\end{array}$ & $\begin{array}{l}752 \\
792\end{array}$ \\
\hline $\left.\begin{array}{l}\text { Not on } \\
\text { Phantom }\end{array}\right\}$ & & $\left\{\begin{array}{l}746 \\
779\end{array}\right.$ \\
\hline $\left.\begin{array}{l}\text { Not on } \\
\text { Phantom }\end{array}\right\}$ & & $\left\{\begin{array}{l}757 \\
669\end{array}\right.$ \\
\hline
\end{tabular}

(a) LASI calculated neutron dose was 708 Rad.

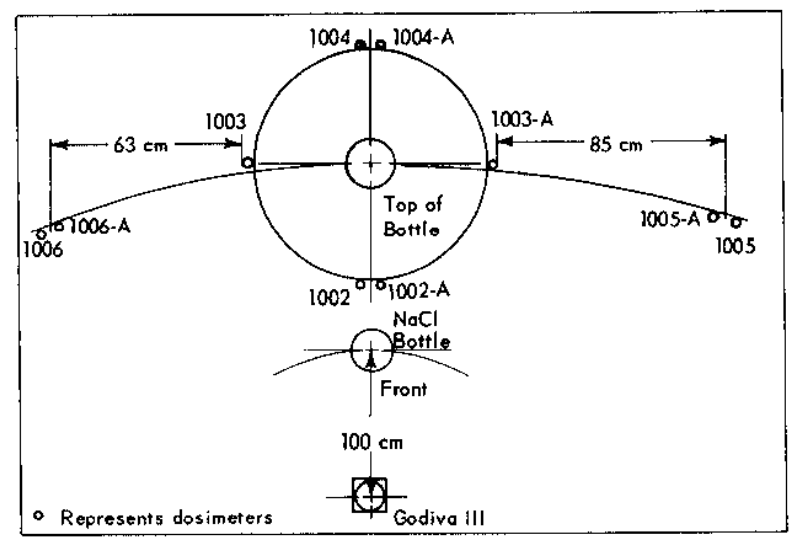

FIG. 4 ARRANGEMENT OF COMPONENTS - GODIVA 
Another test of the system was made at the Health Physics Research Reactor (HPRR) at Oak Rlage National Laboratory. Its primary purpose was to investigate the validity of using salt-solution-filled polyethylene containers as phantoms. In this test pigs were used as phantoms. The thickness of their bodies and the salt content of their blood closely approximates these characteristics in man. Pigs and containers were paired as shown in Figure 5. The average deviation between the doses was $13 \%$, as measured by the dosimeters attached to the containers and pigs.

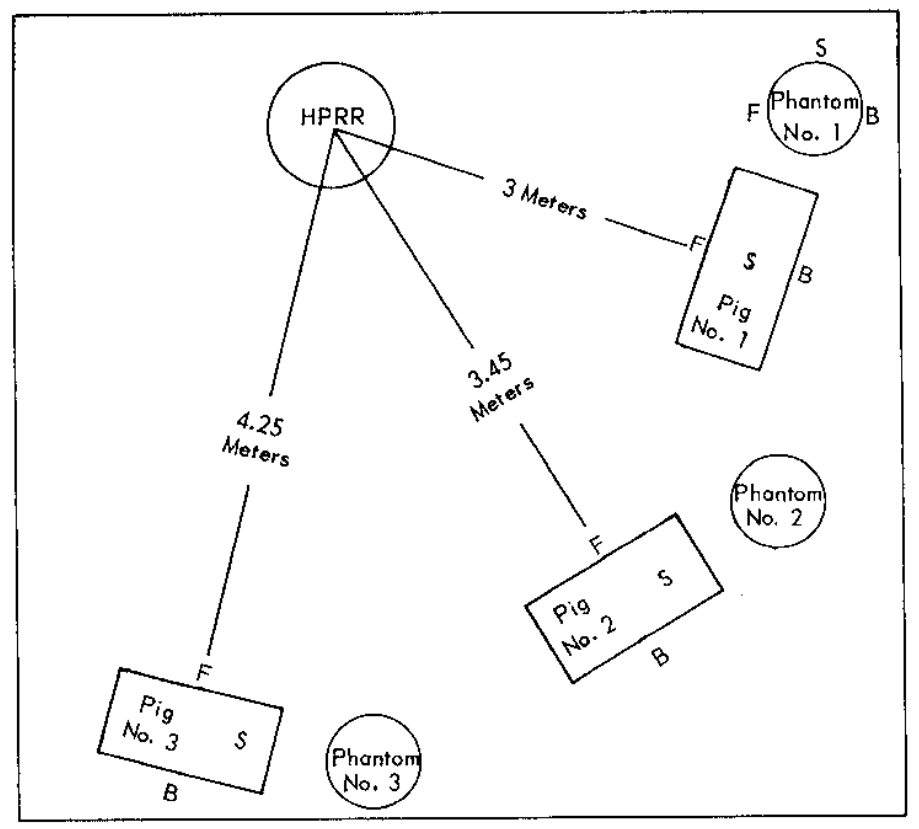

FIG. 5 ARRANGEMENT OF COMPONENTS - HPRR

The entire dosimetry system was tested at HPRR. The dosimeters were exposed, quickly returned to the Savannah River Plant, and processed according to procedures. The people who evaluated the doses had no knowledge of the test conditions. There was close agreement between the results of duplicate dosimeters at each position, and the correct orientation was calculated in the majority of the cases (Table IV). Where errors were made in the calculation of orientation, a front exposure was selected instead of a side exposure. The difference in dose correction factors for these two positions is usually comparatively 
small. These tests showed that the dosimetry system can evaluate doses received by up to 20 workers within six hours after exposure, and can provide a preliminary estimate within one hour.

\section{TABLE IV}

Results of HPRR Test

Dosimeter Position Dosimeter A (a) Dosimeter B(a) $\frac{\begin{array}{c}\text { Computer Calculated Position } \\ \text { Dosimeter Results }\end{array}}{\text { (Neutron Dose), rad }}$

Phantom No. I

$\begin{array}{lllll}\text { Front } & \text { Front } & \text { Front } & 904 & 862 \\ \text { Side } & \text { Side } & \text { Front } & 722 & 753 \\ \text { Back } & \text { Back } & \text { Back } & 856 & 864\end{array}$

Phantom No. 2

Front

S1de

Back

Phantom No. 3

Front

Side

Back

Front
Front
Back

Back

Front

Side

Back
Front

Front

Back.

Front

Front

Back
598

396

568

624

498

554

391

400

373

461

410

484

(a) Two dosimeters were located at each position.

In a more recent test, the criticality dosimeters used at seven nuclear energy facilities in the USA were compared. The dosimeters were exposed to a burst from the HPRR, and the air dose was measured. The SRP results for neutron dose were within three percent( ${ }^{(7)}$ of the average of all results. 


\section{BIBLIOGRAPHY}

1. J. A. Auxier. "The Health Physics Research Reactor." Health Physics. 11, 89-93 (1965).

2. R. C. Axtmann, et al. Initial Operation of the standard Plle. USAEC Report DP-32, E. I. du Pont de Nemours and Company, Savannah River Laboratory, Aiken, S. C. (1953).

3. J. E. Hoy. An Emergency Neutron Dosimeter. USAEC Report DP-472, E. I. du Pont de Nemours and Company, Savannah RIver Laboratory, Aiken, S. C. (1960).

4. C. W. Tittle. "Slow-Neutron Detection by Foils - I." Nucleonics. 8. No. 6, 5-9 (1951); and "Slow-Neutron Detection by Folls - II." Nucleonics. 9, No. 1, 60-67 (1951).

5. Lowell I. Anderson. "Cross Section of Copper-63 for Nuclear Accident Dosimetry." Health Physics. 10, 315-322 (1964).

6. W. S. Snyder. "Protection Against Neutron Radiation Up to 30 Million Electron Volts." National Bureau of Standards Handbook 63, 39-61, Washington, D. C. (1957).

7. "Health Physics Division Annual Progress Report for Perlod Ending July 31, 1965." USAEC Report ORNL-3849, Oak Ridge National Laboratory, Oak Ridge, Tennessee, p. 172 (1965). 


\section{APPENDIX I \\ MANUAL CALCULATION OF CND RESULTS}

In the calculations that follow, the same ldentifying terminology is used in both the computer and manual methods to facilitate comparing the methods.

If the Indium folls are counted less than 10 hours after activation, the 54-minute ${ }^{118}$ In is used for determination. The correction factors used in this case are:

$$
\begin{aligned}
\mathrm{DK} & =\left(1-\mathrm{e}^{\left(-2.16 \times 10^{-4} \mathrm{~T}_{I}\right)}\right) 60 \text { (Buildup Correction) } \\
\mathrm{DKI}= & \mathrm{e}^{\left(-0.0128 \times \mathrm{T}_{21}\right)} \quad \text { (Decay Correction for Bare Indium Fo1I) } \\
\mathrm{DK} 2= & \mathrm{e}^{\left(-0.0128 \times \mathrm{T}_{22}\right)} \quad \text { (Decay Correction for Cd-In Fo1I) } \\
\text { CONST }= & 0.648 \text { (Counter Factor) } \\
\text { ECON }= & 0.102 \text { (Counter Factor) } \\
\text { where, } \mathrm{T}_{1}= & \text { estimated exposure time in seconds } \\
\mathrm{T}_{21}= & \text { decay time in minutes from time of exposure to time } \\
& \text { bare indium foll was counted. } \\
\mathrm{T}_{22}= & \text { decay time in minutes from time of exposure to time } \\
& \text { cadmium-covered indium foll was counted. }
\end{aligned}
$$

If the indium folls are counted after more than 20 hours have elapsed since activation, the 50-day ${ }^{114}$ In is used for the determination. In the interval between 10 hours after exposure and 20 hours after exposure, a mixture of the two isotopes is present, and inaccurate results may be obtained if the folls are counted during this time interval.

$$
\begin{aligned}
\text { The constants used for the }{ }^{114} \mathrm{In} \text { calculations are: } \\
\text { DK }=\left(1-\mathrm{e}^{\left.\left(-1.6 \times 10^{-7}\right) \mathrm{T}_{1}\right) 60}\right. \\
\mathrm{DK} 1=\mathrm{e}^{\left(-9.62 \times 10^{-8}\right) \mathrm{T}_{21}} \\
\mathrm{DK} 2=\mathrm{e}^{\left(-9.62 \times 10^{-6}\right) \mathrm{T}_{22}} \\
\text { CONST }=0.0112 \\
\text { ECON }=7.1
\end{aligned}
$$


Thermal

The thermal flux is calculated using the disintegration rates of the cadmium-shielded indium and bare indium folls as follows:

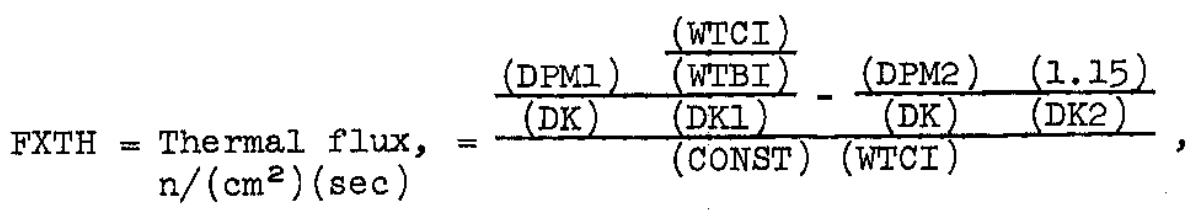

where, $D P M 1=$ net activity $(\mathrm{d} / \mathrm{m})$ of the bare indium foil, not corrected for decay.

DPM2 = net activity $(\mathrm{d} / \mathrm{m})$ of the cadmium-covered indium foil, not corrected for decay.

WTBI $=$ welght of bare indium foll in grams.

WTCI = weight of cadmium-covered indlum foil in grams.

Epithermal $(0.4 \mathrm{eV}$ to $2 \mathrm{eV})$

The epithermal flux is calculated from the activity of the cadmiumcovered indium foll as follows:

$$
\begin{aligned}
\text { EPTHF }= & \text { Epithermal flux, }=\frac{(\text { DPM2 })}{(\text { WTCI })(\mathrm{DK})(\mathrm{DCON})} \\
\mathrm{n} /\left(\mathrm{cm}^{2}\right)(\mathrm{sec}) & (\mathrm{DK})
\end{aligned}
$$

\footnotetext{
Resonance $(2 \mathrm{eV}$ to $1 \mathrm{MeV})$

The resonance flux is calculated from the activity of the copper foll as follows :

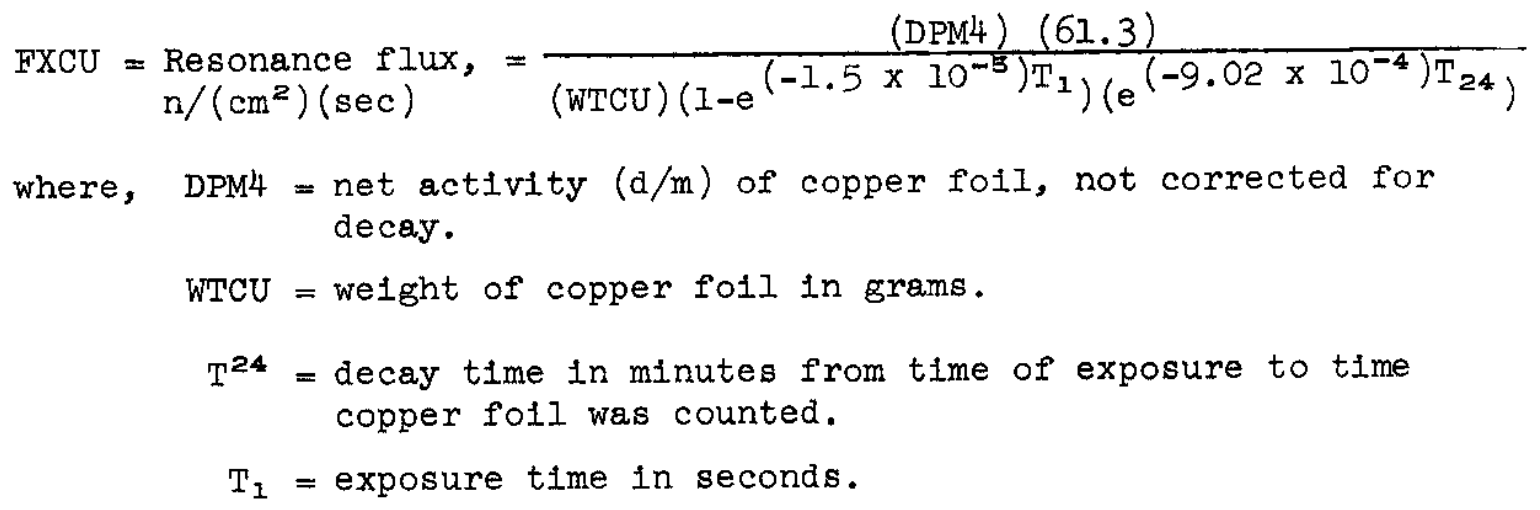


Fast $(3.0$ to $10 \mathrm{MeV})$

The fast flux is determined from activation of the sulfur powder in the CND as follows:

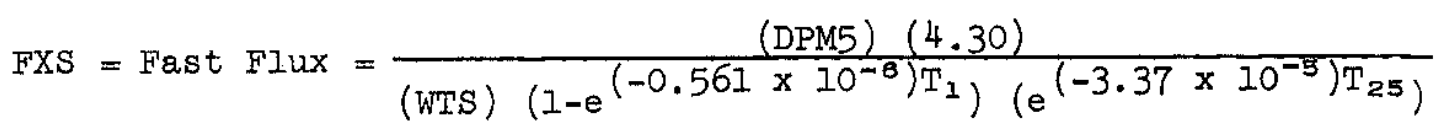

where, DPM5 = net activity $(\mathrm{d} / \mathrm{m})$ of sulfur powder, not corrected for decay.

WTS = weight of sulfur powder in grams.

$\mathrm{T}_{1}=$ exposure time in seconds.

$\mathrm{T}_{25}=$ decay time in minutes from time of exposure to time sulfur was counted.

Medium Energy ( $1-3 \mathrm{MeV})$

The medium and high energy flux is calculated from the activation of the ${ }^{115 \mathrm{~m}}$ In 1somer (4.5-hour half-life) in the cadmium-covered indium foll, as determined by pulse helght analysis. The calculation below determines the total flux above $1 \mathrm{MeV}$.

FXINM = Medium and high energy flux $=$

$$
\frac{(D P M 6)(192.0)}{\left(\text { WTBI }^{\mathrm{T}}\right)\left(1-\mathrm{e}^{\left.\left(-4.28 \times 10^{-5}\right) \mathrm{T}_{1}\right)\left(\mathrm{e}^{\left.(-0.154) \mathrm{T}_{26}\right)}\right.}\right.}
$$

where DPM6 $=\mathrm{c} / \mathrm{m}$ in channels $31-36$ not corrected for decay, but corrected for interference by other indlum isotopes.

$$
\mathrm{T}_{\boldsymbol{2} \boldsymbol{\theta}}=\text { Decay time in hours from time of exposure to time foll }
$$
was counted.

To determine the medium energy flux, subtract the fast flux (above $3 \mathrm{MeV}$ ) as obtained by sulfur counting from the fast and medium flux (above $1 \mathrm{MeV}$ ), as obtained above. The resulting difference is the medium energy flux.

\section{Determination of Directional Corrections}

Since the activity of the folls is influenced by the relative positions of the wearer's body and the exposing source, 1.e., whether 
he had his back to the source or was facing 1t, it is necessary to determine this relationship so that appropriate correction factors may be applied. This 1 s done by calculating the ratio of the ${ }^{24} \mathrm{Na}$ activation in the sodium fluoride powder of the CND and the ${ }^{24} \mathrm{Na}$ activity in a sample of the wearer's blood as follows:

$$
\text { DPGNF }=\frac{(\text { DPM3 })(1.82)}{(\text { WTNAF })\left(e^{\left.\left(-0.75 \times 10^{-3}\right) \mathrm{T}_{23}\right)}\right.}
$$

where, $\mathrm{DPM} 3=$ net activity $(\mathrm{d} / \mathrm{m})$ of sodium fluoride powder not corrected for decay.

WTNAF $=$ welght of the sodium fluoride powder in grams.

$$
\mathrm{T}_{23}=\text { decay time in minutes from time of exposure to time }
$$
sodium fluoride was counted.

$$
\mathrm{DPGBS}=(\mathrm{UCPCC})\left(0.694 \times 10^{\circ}\right)
$$

where, $\quad \mathrm{UCPCC}=\mu \mathrm{c} / \mathrm{cc}$ of ${ }^{24} \mathrm{Na}$ found in the serum of the wearer's blood corrected for decay.

$$
\text { RATIO }=\frac{\text { DPGNF }}{\text { DPGBS }}
$$

Ideally, this ratio would be unity if the sodium fluoride vial was exposed to the same flux as the body of the wearer (side exposure); the vial activity would be higher if it were closer to the source than the wearer (front exposure); and would be lower if the vial were on the opposite side of the person from the source (rear exposure).

In actuality, this ratio is also affected by the relative "hardness," energy-wise, of the spectrum, so that the predicted "ideal" ratio for the spectrum being measured must be calculated from the thermal and fast fluxes as follows:

$$
Y=0.14\left(\frac{\text { Thermal flux }}{\text { Fast flux }}^{0.81}\right.
$$

where, $Y=$ the predicted ratio.

To determine direction, compare the RATIO previously computed with $(Y \pm 0.3 Y)$. If the RATIO falls within these limits, the exposure is calied a "side" exposure, and no directional corrections will be made in calculating dose, 1.e., all correction factors are 1.0 . 
If the RATIO is greater than $(Y+0.3 Y)$, the majority of the dose was received from the front. The following correction factors will be used in dose computation in this case:

$$
\begin{aligned}
& \mathrm{CT}=\text { Thermal correction }=0.23 \\
& \mathrm{CET}=\text { EpIthermal correction }=0.35 \\
& \mathrm{CCU}=\text { Resonance correction }=0.45 \\
& \mathrm{CM}=\text { Medium energy correction }=0.79 \\
& \mathrm{CS}=\text { Fast correction }=0.72
\end{aligned}
$$

If the RATIO is less than ( $Y-0.3 Y$ ), the majority of the dose was recelved from the rear. In this case, the correction factors are:

$$
\begin{aligned}
& \mathrm{CT}=\text { Thermal correction }=0.64 \\
& \mathrm{CET}=\text { Eplthermal correction }=1.6 \\
& \mathrm{CCU}=\text { Resonance correction }=2.0 \\
& \mathrm{CM}=\text { Medium energy correction }=5.4 \\
& \mathrm{CS}=\text { Fast correction }=6.7
\end{aligned}
$$

\section{Dose Calculation}

Thermal dose $($ THRAD $)=$ (Thermal flux) (CT) $\left(0.17 \times 10^{-9}\right)\left(T_{1}\right)$

Epithermal dose (ETRAD) $=$ (Epithermal flux) (CET) $\left(0.22 \times 10^{-8}\right)\left(\mathrm{T}_{1}\right)$

Resonance dose (CURAD) $=$ (Resonance flux) (CCU) $\left(1.25 \times 10^{-9}\right)\left(T_{1}\right)$

Medium Energy dose (RADIN) =(Medium energy flux) (CM) $\left(2.87 \times 10^{-\theta}\right)\left(\mathrm{T}_{2}\right)$

High Energy dose $(\mathrm{SRAD})=$ (Fast flux) (CS) $\left(3.6 \times 10^{-8}\right)\left(\mathrm{T}_{1}\right)$

TOTAL = THRAD + ETRAD + CURAD + RADIN + SRAD = entire neutron dose in Rads. 
APPENDIX ॥

FORTRAN PROGRAM FOR COMPUTATION OF DOSE FROM CND DATA

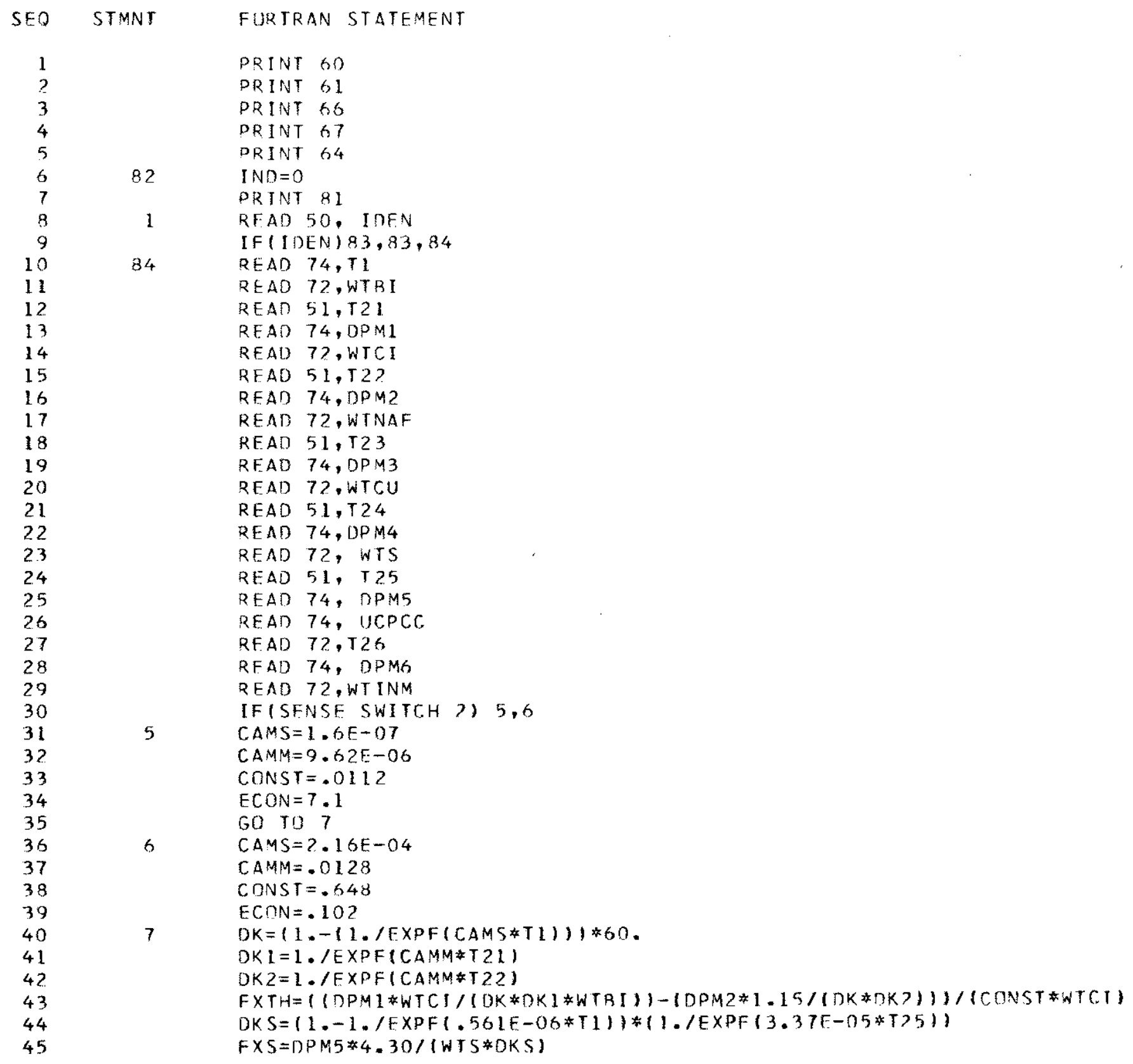


59

60

61

62

63

64

65

66

67

68

69

70

71

72

73

74

75

76

77

78

79

80

81

82

83

84

85

86

87

88

89

90

91

92

93

94

95

96

97

EPTHF $=D P M 2 * E C O N /(W T C 1 * D K * D K 2)$

DKCU $=(1 .-1 . / E X P F(1.5 F-05 * T 1) *(1 . / E X P F(.000902 * T 24))$

FXCU $=$ DPM4 *61.3/(DKCU*WTCU)

DKINM $=(1 .-(1 . / \operatorname{EXPF}((4.28 E-05) * T 1)) *(1 . / \operatorname{EXPF}(1,1.54 \mathrm{E}-01) * T) 6))$

FXINM $=$ DPMG $\$ 192.0 /$ (WTINM*DKINM)

$D P G N F=D P M 3 * 1.82 /($ WTAF* $(1 . / F X P F(.77 E-03 * 123)))$

$D P G B S=U C P C C * .694 F 09$

RATIO=DPGNF/DPGRS

$Y=(0.14) *($ (FXTHIFXS $) * .61)$

PRINT 53, IDEN

PRINT 8O, RATI0,Y

$Y \mathbf{l}=Y+0 * 3 * Y$

$Y 2=Y-0.3 * Y$

IFIRATIO-YII3,3,13

3 IFIRATIO-Y $111,11,12$

$1 \mathrm{I} \quad \mathrm{CT}=.64$

CET $=1.6$

$\mathrm{CCU}=2.0$

$C M=5.4$

$C S=6.7$

PRINT 54

GO TO 20

$12 \quad C T=1.0$

$C E T=1.0$

$\mathrm{CCU}=1.0$

$\mathrm{CS}=1.0$

$C M=1.0$

PRINT 55

GO TO 21

13

$\mathrm{CI}=.23$

$\mathrm{CET}=.35$

$\mathrm{CCU}=.45$

$C M=.79$

$C S=.72$

PRINT 56

20 IFISENSE SWITCHI)12,21

$21 \quad T F \times T H=F X T H * C T * T 1$

$T F \times S=F \times S * C S * T 1$

THTFR $=$ TF $X$ TH $/$ TF $X S$

TFXTH=FXTH T 1

TEPTH=EPTHF*T 1

$T F \times S=F \times S * T 1$

$T F X C U=F \times C U * T 1$

$T F I N M=F \times I N M * T 1$

TINMS = TF INM-TFXS

TFLUX = TFXTH+TEPTH+TFXCU+TINMS+TFXS

$T H R A D=T F X T H * C T * 0.16 E-09$

$E T R A D=T E P T H * C E T * 0.22 E-09$

CURAD $=T F \times C U * C C U * 1.25 E-09$

RADIN $=$ TINMS*CM*2.87E-09

SRAD $=$ IFXS*CS*4.8E-09

$T O T A L=T H R A D+E T R A D+C U R A D+R A D I N+S R A D$ 


\begin{tabular}{|c|c|c|}
\hline SEQ & STMNT & FORTRAN STATEMENT \\
\hline 98 & & PRINT 30 , TFXTH, THRAD \\
\hline 99 & & PRINT 31 , TEPTH, ETRAD \\
\hline 100 & & PRINT $32, T F X C U, C U R A D$ \\
\hline 101 & & PRINT 33 , TINMS, RADIN \\
\hline 102 & & PRINT 34, IF XS, SRAD \\
\hline 103 & & PRINT 35, TFLUX, TOTAL \\
\hline 104 & & PRINI 36, THTFR \\
\hline 105 & & $I N D=I N D+1$ \\
\hline 106 & & IF $(I N D-3) 1,82,82$ \\
\hline 107 & 83 & PRINT 85 \\
\hline 108 & & PRINT 81 \\
\hline 109 & & PAUSE \\
\hline 110 & 30 & FORMAT $115 \mathrm{H}$ THERMAL \\
\hline 111 & 31 & FORMAT $115 \mathrm{H}$ FPITHERMAL \\
\hline 112 & 32 & FORMAT $115 \mathrm{H}$ 2EV TO 1 MEV \\
\hline 113 & 33 & FORMAT(15H 1 MEV TO $3 M E V, E 9.2, F 9.3)$ \\
\hline 114 & 34 & FORMAT $(15 \mathrm{H}$ ABOVE 3MEV ,E9.2,F9.3) \\
\hline 115 & 35 & FORMAT $(1 \times / 15 \mathrm{H}$ TOTAL \\
\hline 116 & 36 & FORMAT $(1 \times / / 16 \mathrm{H}$ THERMAL/FAST,$F 9.2)$ \\
\hline 117 & 50 & FORMAT $(14)$ \\
\hline 118 & 51 & FORMAT $(F 6.0)$ \\
\hline 119 & 53 & FORMATIIX///15H PAYROLL NO. \\
\hline 120 & 54 & FORMAT (IX/14H REAR EXPOSURE) \\
\hline 121 & 55 & FORMAT (IX/14H SIDF EXPOSURE) \\
\hline 122 & 56 & FORMAT (IX/15H FRONT EXPOSURE) \\
\hline 123 & 60 & FORMAT (3OHICND DOSE CALCULATOR NOV. 1965$)$ \\
\hline 124 & 61 & FORMAT $221 \mathrm{H}$ PROGRAM INSTRUCTIONSI \\
\hline 125 & 64 & FORMAT $145 \mathrm{H}$ INDIUM DECAY MORE THAN 20 HOURS SWITCH C ON \\
\hline 126 & 66 & FORMAT $145 \mathrm{H}$ SWITCH B ON TO IGNORE DIRECTIONAL CORRECTIONI \\
\hline 127 & 67 & FORMAT (39H (CALCULATED DIRECTION WILL BE PRINTFD)) \\
\hline 128 & 72 & FORMAT $(F 8.2)$ \\
\hline 129 & 74 & FORMAT (E9.3) \\
\hline 130 & 80 & FORMATITH RAIIO ElO.3,3X2HY E10.3) \\
\hline 131 & 81 & FORMAT $(1 H 1)$ \\
\hline 132 & & END \\
\hline 133 & 85 & FORMAT $(4 \mathrm{Hl}$ EOJ $)$ \\
\hline
\end{tabular}


INPUT DATA TO

FORTRAN PROGRAM FOR COMPUTATION

OF DOSE FROM CND DATA

\begin{tabular}{|c|c|c|c|}
\hline $\begin{array}{l}\text { ntry } \\
\text { No. }\end{array}$ & $\begin{array}{l}\text { Fortran } \\
\text { Format }\end{array}$ & Description & Example \\
\hline $\begin{array}{l}1 \\
2 \\
3 \\
4 \\
5\end{array}$ & $\begin{array}{l}\text { I4 } \\
\text { E9.3 } \\
\text { F8.2 } \\
\text { F6.0 } \\
\text { E9.3 }\end{array}$ & $\begin{array}{l}\text { Identification or badge No. } \\
\text { Exposure time, seconds (may be an estimate) } \\
\text { Welght of bare Indium foll, gram } \\
\text { Decay time before counting bare In foll, minutes } \\
\text { Net activity of bare indium foll, }(a) \mathrm{d} / \mathrm{m}\end{array}$ & $\begin{array}{l}0028 \\
4.320 \mathrm{E}+02 \\
00000.49 \\
00462 \\
1.040 \mathrm{E}+05\end{array}$ \\
\hline $\begin{array}{r}6 \\
7 \\
8 \\
9 \\
10\end{array}$ & $\begin{array}{l}\text { F8.2 } \\
\text { F6.0 } \\
\mathrm{E} 9.3 \\
\text { F8.2 } \\
\text { F6. }\end{array}$ & $\begin{array}{l}\text { Weight of Cd-covered In foll, gram } \\
\text { Decay time before counting Cd-In foll, minutes } \\
\text { Net activity of Cd-In foll, (a) d/m } \\
\text { Weight of sodium fluoride powder, gram } \\
\text { Decay time before counting NaF, minutes }\end{array}$ & $\begin{array}{l}00000.34 \\
00465 . \\
2.140 E+04 \\
00000.99 \\
00507\end{array}$ \\
\hline $\begin{array}{l}11 \\
12 \\
13 \\
14 \\
15\end{array}$ & $\begin{array}{l}\text { E9.3 } \\
\text { F8.2 } \\
\text { F6.0 } \\
\text { E9.3 } \\
\text { F8.2 }\end{array}$ & $\begin{array}{l}\text { Net activity of NaF powder, }(a) \mathrm{d} / \mathrm{m} \\
\text { Welght of copper foll, gram } \\
\text { Decay time before counting copper foil, minutes } \\
\text { Net activity of copper foll, }(\mathrm{a}) \mathrm{d} / \mathrm{m} \\
\text { Welght of sulfur powder, gram }\end{array}$ & $\begin{array}{l}3.570 \mathrm{E}+04 \\
00000.44 \\
00599 \\
2.330 \mathrm{E}+03 \\
00001\end{array}$ \\
\hline $\begin{array}{l}16 \\
17 \\
18 \\
19 \\
20 \\
21\end{array}$ & $\begin{array}{l}\text { F6.0 } \\
\text { E9.3 } \\
\text { E9.3 } \\
\text { F8.2 } \\
\text { E9.3 } \\
\text { F8.2 }\end{array}$ & $\begin{array}{l}\text { Decay time before counting sulfur powder, minutes } \\
\text { Net activity of sulfur powder, }(\mathrm{a}) \mathrm{d} / \mathrm{m} \\
{ }^{24} \mathrm{Na} \text { in blood sample at } \mathrm{t}=0, \mu \mathrm{c} / \mathrm{cc} \\
\text { Decay time (b) before counting for } 115 \mathrm{~m}_{\mathrm{In}} \text {, hours } \\
\text { Net activity of } 11 \mathrm{sm}_{\mathrm{In}} \text {, channels } 31-36, \mathrm{c} / \mathrm{m} \\
\text { Welght of In foll used for }{ }^{115} \mathrm{In} \text { measurement, } \\
\text { gram }\end{array}$ & $\begin{array}{l}01313 \\
9.400 \mathrm{E}+02 \\
4.721 \mathrm{E}-04 \\
000025.92 \\
7.920 \mathrm{E}+01\end{array}$ \\
\hline
\end{tabular}

(a) $(\mathrm{d} / \mathrm{m}=$ net $\mathrm{c} / \mathrm{m} \times \mathrm{CF}$ (Ra D\&E), not corrected for decay.

(b) Decay time for this item only $1 \mathrm{~s}$ in HOURS; all others are in minutes. 